EDUKACJA MIĘDZYKULTUROWA

2013, nr 2

ISSN 2299-4106

MareK Rembierz

\title{
Polskie doświadczenie wielokulturowości w interpretacji Jana Pawła II jako inspiracja dla edukacji międzykulturowej
}

Edukacja międzykulturowa, opowiadajac się za wzajemnym wzbogaceniem kultur [...] wnika w istotę kultur, przygotowujac do dialogowych interakcji poprzez wzajemne porównywanie i odnoszenie. Dostarcza treningu inności i obcości, umożliwia odpowiednie tworzenie i modelowanie własnej kultury z jednoczesnym nabywaniem postawy tolerancji i uznania wobec innych kultur

Jerzy Nikitorowicz ${ }^{1}$

Przystępując do problematyki określonej powyższym tytułem, trzeba - na wstępie - zmierzyć się z trafnym spostrzeżeniem Helmuta Jurosa, iż „po śmierci Jana Pawła II można zauważyć pospieszną [...] »wyprzedaż« wszelakich artykułów pozostałych po długim pontyfikacie. Jak sklepikarze pozbywają się po niższej cenie swoich dewocyjnych zapasów, takich jak [...] portrety papieża, tak kandydaci do stopni i tytułów naukowych chcieliby [...] możliwie szybko wykorzystać bogate nauczanie papieskie jako źródło do łatwych opracowań. Instynktownie wyczuwają, że tak jak dziś nikt już nie pisze prac dyplomowych o nauczaniu społecznym Pawła VI, [...], za niedługo zdezaktualizują się także teksty Jana Pawła II. [...] Widoczny dziś pośpiech w przygotowywaniu różnych opracowań myśli papieskiej musi prowadzić do powierzchownych wyników badań" ${ }^{2}$. W prowadzonych tu dociekaniach uwzględnić

1 J. Nikitorowicz: Pogranicze - Tożsamość - Edukacja międzykulturowa. Białystok 2001, „Trans Humana”, s. 124, zob. też s. 167 i s. 35.

2 H. Juros: Nauka, polityka naukowa i ludzie nauki w życiu Karola Wojtyty. Przyczynek do biografii naukowej Profesora i Papieża. „Nauka” 2005 nr 3, s. 9. H. Juros dopowiada, iż pospiesznie ukazujące się publikacje „[nie poprawią] bilansu dotychczasowych badań nad twórczością naukową Karola Wojtyły i papieskiego nauczania Jana Pawła II". Ks. prof. zw. dr hab. H. Juros był kierownikiem naukowym Studium Generale Europa, kierownikiem Katedry Etyki Społecznej, kuratorem Kierunku Po- 
należy dobitnie wyrażoną przestrogę przed pozorowaniem rzetelnych rozważań i żerowaniem na - cieszącym się zainteresowaniem i u niektórych też uznaniem - dorobku. Tym bardziej przekonująco powinno się więc wykazać, iż dokonana przez Jana Pawła II interpretacja polskiego doświadczenia wielokulturowości nie zdezaktualizowała się i może ona być współcześnie inspiracją dla edukacji międzykulturowej.

Mimo odnotowanych na początku zastrzeżeń argumentu przemawiającego na rzecz podjęcia wyznaczonej tytułem problematyki dostarcza m.in. Ewa Ogrodzka-Mazur w konkluzji swych badań nad relacjami między społecznym nauczaniem Jana Pawła II i światem wartości w wychowaniu młodzieży z pogranicza: „Jan Paweł II stał się symbolem i orędownikiem prawdy dla wielu młodych ludzi w nowym, XXI wieku i zarazem jego propozycja osobowego wychowania jednostki do wartości miłości, prawdy i odpowiedzialności zyskuje na znaczeniu wśród różnych, alternatywnych koncepcji wychowania i może znaleźć [...] zastosowanie we współczesnej edukacji społeczeństw wielokulturowych"3. Wspomniane tu postrzeganie postaci i myśli papieża jako „symbolu i orędownika prawdy” wymaga także uwzględnienia przy rozpatrywaniu myśli Jana Pawła II, gdyż odgrywa społecznie ważną rolę w niektórych sposobach odczytania jego nauczania i recepcji nasyconego treściami symbolicznymi przesłania jego pontyfikatu.

Argumentu za refleksją nad dokonaną przez Jana Pawła II interpretacją polskiego doświadczenia wielokulturowości, jako inspiracją dla edukacji międzykulturowej, dostarcza też Juros, zwracając uwagę na problematykę partykularności i uniwersalności: „Nauki społeczne stoją nawet przed szansą dokonania rewelacyjnych odkryć »socjologicznych « w badaniach nad pon-

litologii i Nauk Społecznych oraz dyrektorem Instytutu Nauk Politycznych Akademii Teologii Katolickiej Uniwersytetu Kardynała Stefana Wyszyńskiego w Warszawie (w latach 1987-1990 rektor ATK). Zob. m.in. H. Juros: Piotr naszych czasów. „Więź” 1983 nr 8-10, s. 197-201; tenże: Nowe zadania Kościoła w Polsce. „Przegląd Powszechny" 1993, nr 1 (857), s. 13-29.

3 E. Ogrodzka-Mazur: Społeczne nauczanie Jana Pawła II a mitość, prawda i tolerancja $w$ wychowaniu mtodzieży z pogranicza. W: T. Lewowicki, A. Różańska, U. Klajmon (red.): Kwestie wyznaniowe w społecznościach wielokulturowych. Cieszyn 2002, UŚ - Filia w Cieszynie, s. 262. Zob. też: M. Jędraszewski: Wybrać większq wolność. Karol Wojtyta o człowieku. Poznań 2004, Księgarnia św. Wojciecha; K. Olbrycht: Prawda, dobro i piękno w wychowaniu człowieka jako osoby. Katowice 2002, UŚ (zawarte są tu m.in. analizy możliwości budowania koncepcji wychowania personalistycznego na podstawie myśli personalistycznej K. Wojtyły). 
tyfikatem Jana Pawła II. Stwarza ją problematyka partykularności i uniwersalności. Są to perspektywy, które przecinają się w działalności Jana Pawła II. Jego osobowość jest katalizatorem tych dwóch kolektywnych sił. Czerpał je ze źródeł zarówno narodowych, jak i ogólnoludzkich, to jest z Kościołów lokalnych i Kościoła powszechnego. Godna przeanalizowania jest kwestia, jak Wojtyła korzystał z zasobów duchowych poszczególnych narodów dla odnowy Kościoła powszechnego w skali globalnej"4. Podejmując wskazany tu trop (acz dystansując się od rozważań wprost dotyczących uwarunkowań „odnowy Kościoła powszechnego”), należy zauważyć, iż zagadnienie partykularności i uniwersalności kultury zalicza się do jednych z bardziej istotnych dla badań w zakresie edukacji międzykulturowej.

$\mathrm{Na}$ intelektualne walory rozważań prowadzonych przez Jana Pawła II zwraca uwagę Józef Tischner: „Charakterystyczną cechą stylu Jana Pawła II jest otwieranie horyzontów. Chodzi o to, by przez stawianie podstawowych pytań i przypominanie podstawowych wartości ustanowić najgłębszą inspirację dla nowego sposobu bycia człowiekiem”. Jeśli „styl Jana Pawła II” ma zasługiwać na tak wysoką ocenę, zdecydowanie zachęcającą do zapoznania się z papieskimi przemyśleniami, to tym bardziej wydaje się słusznym zamysł rozważenia, na ile owo „otwieranie horyzontów” ujawnia się również w papieskiej interpretacji polskiego doświadczenia wielokulturowości, na ile ta interpretacja skłania do podjęcia podstawowych pytań i do zwrócenia uwagi na podstawowe wartości, w jakim zakresie może być ona inspiracją dla teorii i praktyki edukacji międzykulturowej, dla kształtowania aksjologicznie zasadnego i odpowiedniego w obliczu współczesnych wyzwań sposobu bycia człowiekiem.

\section{Kultura i wychowanie $w$ aspekcie partykularności i uniwersalności}

Kultura, również w aspekcie jej partykularności i uniwersalności, była przedmiotem dociekań Jana Pawła II, zwłaszcza w uznawanym za programowe przemówieniu wygłoszonym 2 czerwca 1980 roku w UNESCO. Najpierw - idąc za myślą Tomasza z Akwinu: Genus humanum arte et ratione viviti

4 H. Juros: Nauka, polityka naukowa i ludzie nauki w życiu Karola Wojtyty. Przyczynek do biografi naukowej Profesora i Papieża. cyt. wyd., s. 15.

5 J. Tischner: Między miłosierdziem a okrucieństwem. W: tenże: Idąc przez puste Błonia. Wybór i oprac. W. Bonowicz. Kraków 2005, „Znak”, s. 59. 
- zwrócił uwagę na „fakt antropologiczny” istotnego zespolenia osoby ludzkiej z kulturą: „Człowiek żyje prawdziwie ludzkim życiem dzięki kulturze. [...] Kultura jest właściwym sposobem istnienia i bytowania człowieka", aby następnie zaproponować ujęcie relacji między wielością kultur i jednością kultury: „Człowiek bytuje zawsze na sposób jakiejś kultury sobie właściwej, która z kolei stwarza pomiędzy ludźmi właściwą dla nich więź, stanowiąc o międzyludzkim i społecznym charakterze ludzkiego bytowania. Stąd też w jedności kultury, jako właściwego sposobu istnienia człowieka, bierze zarazem początek wielość kultur, wśród których człowiek bytuje. W tej wielości człowiek rozwija się, nie tracąc istotnego kontaktu z jednością kultury jako podstawowego i istotnego wymiaru swego istnienia i bytowania"6. Takiemu ujęciu funkcji kultury i jej funkcjonowania w wielości i jedności towarzyszy mocne (określane jako „integralne”) aksjologiczno-antropologiczne założenie dotyczące ludzkiej godności: „Ażeby tworzyć kulturę, trzeba do końca i integralnie widzieć człowieka jako szczególną, samoistną wartość, jako podmiot związany z osobową transcendencją. Trzeba tego człowieka afirmować dla niego samego, nie dla jakichkolwiek innych racji czy względów - jedynie dla niego samego! Trzeba tego człowieka po prostu miłować dlatego, że jest człowiekiem - trzeba wymagać dla niego miłości ze względu na szczególną godność, jaką posiada"? Tworzenie kultury, służące afirmacji osoby ze względu

6 Jan Paweł II: W imię przyszłości kultury. Przemówienie w siedzibie UNESCO, Paryż, 2 VI 1980. W: tenże: Wiara i kultura. Dokumenty, przemówienia, homilie. Wybór i oprac. M. Radwan, S. Wylężek, T. Gorzkula. Rzym - Lublin 1988, KUL, s. 54. Zob. też: G. Kalinowski: Nauka i kultura w stużbie człowieka: Jan Pawet II. „Communio". Międzynarodowy Przegląd Teologiczny 1998, nr 5, s. 58-66.

7 Tamże, s. 57-58. Jan Paweł II głoszone przez siebie przekonania aksjologiczno-antropologiczne bezpośrednio wiąże z przesłaniem ewangelicznym: „Otóż ten zespół treści należy do samej istoty ewangelicznego orędzia Chrystusa i posłannictwa Kościoła, bez względu na wszystko, co w tej sprawie wypowiedziały krytyczne umysły oraz czego dokonały różne prądy niechętne religii w ogóle, a chrześcijaństwu w szczególności” (tamże, s. 58). Wypracowana przez papieża filozofia i teologia osoby nie zawsze są pozytywnie odbierane w kręgach kościelnych; budzą one wątpliwości, a nawet sprzeciw. Współpracownik papieża, kard. Paul Poupard, wspomina o niezrozumieniu, na które natrafił, gdy pierwszy raz przytoczył na pewnym forum kościelnym - zasadnicze dla pontyfikatu Jana Pawła II - słowa: „Trzeba kochać człowieka dla niego samego i dla niczego innego!”. Otóż: „Niektórzy [...] mówili: »Ależ to jest bluźniercze! Trzeba kochać człowieka ze względu na Boga «". P. Poupard nie zgadza się z krytykami papieża, posądzającymi go o „personalistyczne bluźnierstwo”; argumentując na rzecz antropologii papieża podaje też racje teologiczne: „Nie! »Trzeba kochać człowieka dla 
na jej godność, nakłada zarazem powinność wychowania: „pierwszym i zasadniczym zadaniem kultury w ogóle i każdej zarazem kultury jest wychowanie. W wychowaniu bowiem chodzi właśnie o to, ażeby człowiek stawał się coraz bardziej człowiekiem [...], umiał bardziej i pełniej być człowiekiem [...], ażeby również umiał bardziej »być« nie tylko z »drugimi«, ale także i dla »drugich«. Wychowanie posiada podstawowe znaczenie dla kształtowania stosunków międzyludzkich i społecznych"8. Kwestia partykularności i uniwersalności kultury wymaga więc refleksji i wypracowania odpowiednich rozstrzygnięć przede wszystkim ze względu na właściwie pojętą edukację, gdyż wychowanie do bycia z „drugimi” i „dla drugich” ma być głównym zadaniem kultury w jej ogólności i w każdej jej konkretnej postaci.

W ten sposób określone zasadnicze i niezbywalne funkcje wychowania w kulturze - w kontekście jej partykularności i uniwersalności - prowadzą w stronę tego typu działań wychowawczych, które podejmować też powinna edukacja międzykulturowa ${ }^{9}$, mająca - jak ujmuje to Nikitorowicz, odnosząc

niego samego, a nie z żadnej innej przyczyny« - nie przestaje powtarzać Jan Paweł II, począwszy od swojego programowego przemówienia w UNESCO, ponieważ jeżeli kocha się go dla niego samego, kocha się go jako obraz i podobieństwo Boga" (Kard. P. Poupard: Ten papież jest darem od Boga. Rozmowa z Marie-Joelle Guillaume. Wstęp abp J. Życiński. Katowice 2002, Księgarnia św. Jacka, s. 48). Kardynał Paul Poupard był przewodniczącym Papieskiej Rady ds. Kultury. Zob. też: K. Wolsza: Aksjologiczna struktura człowieka a problem ontycznych podstaw moralności. W: P. Morciniec (red.): Ocalić obraz człowieka. Antropologiczne podstawy moralności. Opole 2003, UO, s. 11-26.

8 Tamże, s. 58; zob. też: P. Dancák: Otázka výchovy v náuke Jána Pavla II. Prešov 2001, Petra; tenże: Výchova k slobode ako prejav zodpovednosti za život vo filozofickej reflexii Jána Pavla II. „Theologos” 2003, nr. 1, s. 94-105.

9 Zob. T. Lewowicki: Edukacja międzykulturowa - bilans otwarcia 2012. „Edukacja Międzykulturowa” 2012, nr 1, s. 15-46 („Edukacja ma powinność kształtowania świata wartości, wiedzy, postaw, które prowadzić będą do pokojowego współistnienia, tolerancji, współpracy, godnych warunków życia, respektowania praw człowieka, wolności. Szczególne miejsce i rolę przypisać należy szeroko pojmowanej edukacji międzykulturowej", tamże, s. 15); tenże: W poszukiwaniu modelu edukacji międzykulturowej. W: T. Lewowicki, E. Ogrodzka-Mazur, A. Szczurek-Boruta (red.): Edukacja międzykulturowa w Polsce i na świecie. Katowice 2000, UŚ, s. 21-35. „Edukacja międzykulturowa jako troska o wspólnotowy rozwój społeczeństw, postrzegana jako pedagogika spotkania i konfliktu kultur, proponuje paradygmat współistnienia, dialogu, porozumienia, negocjacji i kooperacji. Wymaga ona otwartości na inne społeczności i ich kulturę"; A. Szczurek-Boruta: Edukacja i odkrywanie tożsamości w warunkach 
się przy tym do polskiej sytuacji - „trudne do realizacji zadania związane z kształtowaniem potrzeby »wychodzenia na pogranicza«, wydobywania tradycji pluralizmu kultury polskiej, pielęgnowania wspólnego dziedzictwa kulturowego, postrzegania i interpretowania inności jako ciekawej i motywującej do rozwoju i współpracy"10. W nasyconej treściami aksjologicznymi edukacji międzykulturowej podjęta powinna zostać „idea kształtowania społeczeństwa otwartego, programowe nieizolowanie się od innych kultur, jak też programowe nawiązywanie do wkładu kultur niepolskich w proces kształtowania się narodu polskiego"; choć towarzyszy temu świadomość, iż idea prowadzenia takich działań pedagogicznych "jest ideą trudną do realizacji" ${ }^{11}$. Dzięki tak ukierunkowanej edukacji ma się kształtować pożądane sprawności intelektualne i cechy charakteru, służące efektywnemu komunikowaniu międzykulturowemu, będącemu w jakiejś mierze „przekraczaniem granic własnej kultury, wychodzeniem na pogranicza, styki kulturowe po to, aby stawać się bogatszym wewnętrznie"12. Rozpatrując warunki sprzyjające edukacji międzykulturowej, rozróżnia się dwa modelowe typy społeczeństwa: (1) społeczeństwo promujące kształtowanie postaw zamkniętych, gdyż jest ono uformowane w ten sposób, iż „nie stwarza sytuacji do kontaktów z innością i [...] nie zawiera w sobie różnorodności w sferze kulturowej, etnicznej, wyznaniowej”; (2) „społeczeństwo, które dostarcza takich kontaktów, pielęgnuje i ceni inność, pozwala na trening obcości, stwarza warunki do spostrzegania rzeczywistości społecznej jako urozmaiconej"13. Wyróżnionym

wielokulturowości. Szkice pedagogiczne. Katowice - Cieszyn - Kraków 2007, UŚ, Oficyna Wydawnicza „Impuls”, s. 30.

10 J. Nikitorowicz: Pogranicze - Tożsamość - Edukacja międzykulturowa. cyt. wyd., s. 169. Zob. też: tenże: Edukacja regionalna i międzykulturowa. Warszawa 2009, WAiP; tenże: Edukacja międzykulturowa. W: T. Pilch (red.): Encyklopedia pedagogiczna XXI wieku. T. 1. Warszawa 2003, „Żak”, s. 934-941.

11 Tamże.

12 Tamże, s. 8.

13 Tamże, s. 18. J. Nikitorowicz przywołuje z aprobatą pogląd F. Znanieckiego, że „twórczy rozwój ludzkości wymaga, aby człowiek uczestniczył aktywnie co najmniej w dwu kulturach, doceniając obie" (tamże, por. s. 35); tenże: Fenomen wielokulturowości i prognozy rozwoju ku międzykulturowości. „Edukacja Międzykulturowa” 2012, nr 1, s. 47-66 („Dotychczasowe doświadczenia w zakresie badań nad wielokulturowością coraz bardziej upewniają w tym, że szczególnie istotnym problemem jest potrzeba wypracowania nowej koncepcji kultury wiedzy o sobie $i$ innych, co może i powinna podjąć edukacja międzykulturowa", tamże, s. 47). 
i przeciwstawionym tu dwóm typom społeczeństwa towarzyszą dwa przeciwstawne modele tożsamości: zamkniętej i otwartej. Tożsamość zamknięta - jak stwierdza Leon Dyczewski - jest własnością jednostek, które „na ogół słabo znają elementy swojej tożsamości, ale wykazują silny z nimi związek emocjonalny, są do nich mocno przywiązane. Dyskusja z nimi na ich temat jest raczej trudna. Nie są też zbyt otwarte na przyjmowanie elementów z obcej kultury. Są skłonne do tworzenia i utrwalania stereotypów i uprzedzeń wobec »innych «. Traktują ich jako obcych, którzy im zagrażają. Stanowią podatny grunt dla kształtowania się postaw etnocentrycznych i szowinistycznych”. Natomiast postawy określane mianem „tożsamości otwartej” dotyczą tych jednostek, które „na ogół dobrze znają jej elementy, potrafią je innym wyjaśnić i na ich temat dyskutować. Są otwarte na »innych «, łatwo przyswajają sobie ich kody znaczeniowe i podejmują z nimi działania bez obaw zagubienia własnej tożsamości. [...] im większa akceptacja swojej tożsamości i pełniejsza jej świadomość, tym większa otwartość na »innego«, »innych«, bez obawy zatracenia własnej tożsamości"14. W stronę kształtowania tak właśnie pojętej - dynamicznej, dojrzałej i spójnej - tożsamości otwartej, a przezwyciężania - niepewnej siebie, niestabilnej emocjonalnie i zalęknionej - tożsamości zamkniętej i jej reliktów, zmierzają też postulaty Jana Pawła II, dotyczące celów i metod wychowania w kontekście partykularności i uniwersalności kultury.

W obszary właściwe edukacji międzykulturowej Jan Paweł II wchodził częstokroć. Dał temu wyraz m.in. w przemówieniu do uczestników sympozjum poświęconego Europie (14 I 1999): „Skoro otworzyły się granice państw, nie należy dopuścić, aby powstały nowe bariery między ludźmi i nowe nieprzyjaźnie między narodami na tle ideologicznym. Poszukiwanie prawdy winno być motorem wszelkich działań na płaszczyźnie kultury oraz budowania braterskich relacji na kontynencie. Wymaga to pełnego poszanowania

14 L. Dyczewski: Od tożsamości zamkniętej do otwartej w społeczeństwie wielokulturowym i globalnym. W: T. Lewowicki, J. Urban, A. Szczypka-Rusz (red.): Język, komunikacja i edukacja w spotecznościach wielokulturowych. Cieszyn - Warszawa 2004, UŚ - Filia w Cieszynie, Wyższa Szkoła Pedagogiczna ZNP w Warszawie, s. 61. Zob. też: E. Ogrodzka-Mazur: Kategoria tożsamości w analizach zmiany społecznej. Implikacje pedagogiczne do badań edukacji międzykulturowej. W: T. Lewowicki, E. Ogrodzka-Mazur (red.): W poszukiwaniu teorii przydatnych w badaniach międzykulturowych. Cieszyn 2001, UŚ - Filia w Cieszynie, s. 55-68; A. Szczurek-Boruta: Edukacja $i$ odkrywanie tożsamości w warunkach wielokulturowości - szkice pedagogiczne. cyt. wyd.; Z. Bokszański: Tożsamości zbiorowe. Warszawa 2005, PWN. 
człowieka i jego praw, poczynając od wolności słowa i wolności religii. Dlatego ważne jest, aby nasi współcześni otrzymywali autentyczne wykształcenie oparte na istotnych wartościach duchowych, moralnych i obywatelskich. Dzięki temu każdy człowiek uświadomi sobie swoje szczególne powołanie i wyjątkowe miejsce w ludzkiej wspólnocie i w służbie braciom"15. Zwracając uwagę na podstawowy zestaw wartości (duchowych, moralnych i obywatelskich), przyjmując przy tym, iż wartości są „światłami, które rozjaśniają bytowanie, a w miarę jak człowiek pracuje nad sobą, coraz intensywniej świecą na horyzoncie jego życia”"16 i proponując rozumienie „autentycznego wykształcenia", Jan Paweł II wprost jakby określał aksjologiczne fundamenty i zadania edukacji międzykulturowej w zgodzie z przyjętą wykładnią europejskiej tożsamości: „Słowo »Europa « winno oznaczać »otwartość«. Domaga się tego sama jej historia, pomimo przeciwnych doświadczeń i znaków, których nie brakowało: »Europa naprawdę nie jest terytorium zamkniętym ani izolowanym, gdyż kształtowała się przez kontakty z zamorskimi ludami, kulturami i cywilizacjami « ${ }^{17}$. Dlatego winna być kontynentem otwartym i gościnnym $[\ldots]^{\prime \prime}$. Myśl ta wyrażana jest po wielokroć w różnych wystąpieniach, w któ-

15 Jan Paweł II: Chrystus - źródto nowej kultury dla Europy. Do uczestników przedsynodalnego sympozjum poświęconego Europie (14 I 1999). „L'Osservatore Romano" wyd. polskie 1999, nr 3, s. 20-21. Od 11 do 14 stycznia 1999 r. odbyło się w Rzymie międzynarodowe sympozjum Papieskiej Rady ds. Kultury (w ramach przygotowań do II Specjalnego Zgromadzenia Synodu Biskupów poświęconego Europie), w którym uczestniczyło około 50 filozofów, teologów, kulturoznawców i historyków z 35 krajów Europy, m.in. Stanisław Grygiel, Zbigniew Nosowski i Krzysztof Zanussi. Zob. P. Dancák: Communio personarum a európska integrácia. W: P. Dancák (red.): Sapienciálny charakter antropológie Jána Pavla II. v kontexte európskej integrácie. Zborník z vedeckého seminára s medzinárodnou účastou. Prešov 2006, Gréckokatolícka teologická fakulta Prešovskej univerzity v Prešove, s. 112-127.

16 Jan Paweł II: Pamieć i tożsamość. Rozmowy na przełomie tysiacleci. Kraków 2005, „Znak”, s. 35.

17 Jan Paweł II: List do kard. Miloslava Vlka, przewodniczacego Rady Konferencji Episkopatów Europy (16 października 2000 r.). „L'Osservatore Romano” wyd. polskie 2001, nr 1, s. 46.

18 Jan Paweł II: Posynodalna adhortacja apostolska „Ecclesia in Europa” (nr 111). Zob też: E. Ogrodzka-Mazur „Nowy nieporzadek świata” a kształtowanie (się) tożsamości globalnej. Ku pedagogice odpowiedzialności w XXI wieku. W: T. Lewowicki, E Ogrodzka-Mazur, J. Urban (red.): Społeczne uwarunkowania edukacji międzykulturowej. Konteksty teoretyczne. T. 1. Cieszyn - Warszawa - Toruń 2009, Wydział Etnologii i Nauk o Edukacji Uniwersytetu Śląskiego, Wyższa Szkoła Pedagogiczna ZNP 
rych papież przedstawia wizję europejskiej jedności ducha: „Jest nam bardzo potrzebna głęboka motywacja duchowa, aby Europa pozostała kontynentem otwartym i gościnnym oraz by godność naszych braci nie była poniżana, ponieważ racją bytu społeczeństwa jest to, iż pozwala ono każdemu człowiekowi prowadzić »życie naprawdę ludzkie« (Jacques Maritain, L’homme et l'Etat, 11)"19. Potrzeba urzeczywistniania tak ukierunkowanej edukacji międzykulturowej oparta zostaje nie tylko na interpretacji europejskiej aksjologii otwartości, ale też na przyjętym założeniu metafizyczno-antropologicznym: „Kultury, jeśli są głęboko zakorzenione w ludzkiej naturze, odznaczają się typową dla człowieka otwartością na wymiar uniwersalny i na transcendencję" (Fides et ratio, 70). Trzeba przy tym uwzględnić, iż to ujęcie kultury wedle Jana Pawła II było odczytane i potwierdzone w polskim doświadczeniu historycznym, którego on czuje się dziedzicem i uczestnikiem. Szczególne świadectwo tym przekonaniom dał - dokonując terminologicznych rozróżnień i zarazem wypowiadając się $\mathrm{w}$ osobistym tonie - w przemówieniu w UNESCO (Paryż, 2 VI 1980): „Jestem synem Narodu, który przetrwał najstraszliwsze doświadczenia dziejów, który wielokrotnie sąsiedzi skazywali na śmierć a on pozostał przy życiu, i pozostał sobą. Zachował własną tożsamość i zachował pośród rozbiorów i okupacji własną suwerenność jako Naród - nie w oparciu o jakiekolwiek inne środki fizycznej potęgi, ale tylko w oparciu

w Warszawie, Wydawnictwo Adam Marszałek, s. 85-99; E. Ogrodzka-Mazur stwierdza: „W Europie obserwujemy z jednej strony - procesy jednoczenia się państw oraz wiążące się z nimi tendencje homogenizacyjne, a z drugiej - wzrost znaczenia odrębności regionalnych. Postępujące w obszarze polityki i ekonomii ujednolicenie stało się przyczyną ingerencji w poczucie odrębności istniejących od dawna społeczności kulturowych. W odpowiedzi na te zjawiska pojawiły się tendencje do eksponowania i obrony kultur regionalnych, etnicznych i narodowych. Kultura zatem, w przeciwieństwie do wielu innych sfer życia, pozostaje wciąż fenomenem wielowymiarowym. W owej przestrzeni współwystępują oraz przenikają się ponadnarodowe, narodowe i regionalne tradycje, historia, wartości duchowe i moralne, przy czym owa koegzystencja jest zjawiskiem coraz silniej eksponowanym zarówno w skali europejskiej, jak i światowej", tamże, s. 85; R. Zenderowski: Religia a tożsamość narodowa i nacjonalizm $w$ Europie Środkowo-Wschodniej. Między etnicyzacja religii a sakralizacją etnosu (narodu). Wrocław 2011, UWr.

19 Jan Paweł II: Przemówienie do grupy chrześcijańskich deputowanych do Parlamentu Europejskiego, Rzym, 6 marca 1997. W: S. Sowiński, R. Zenderowski: Europa droga Kościoła. Jan Pawet II o Europie i europejskości. Wrocław 2003, Zakład Narodowy im. Ossolińskich, s. 267. Zob. L. Dyczewski: Wizjoner Europy, „Ethos” 2003, nr 3-4, s. 207-226. 
o własną kulturę, która okazała się w tym wypadku potęgą większą od tamtych potęg. I dlatego też to, co tutaj teraz mówię [...], nie jest echem żadnego nacjonalizmu, ale pozostaje trwałym elementem ludzkiego doświadczenia i humanistycznych perspektyw człowieka. Istnieje podstawowa suwerenność społeczeństwa, która wyraża się w kulturze Narodu. Jest to ta zarazem suwerenność, przez którą równocześnie najbardziej suwerenny jest człowiek" ${ }^{20}$. Suwerenność kultury i narodu ma być gwarancją podmiotowości i suwerenności osoby ludzkiej, która urzeczywistnia się w danej kulturze.

Zagadnienie zespolenia partykularności i uniwersalności kultury występuje również w - mającej wymiar edukacyjny i auto-edukacyjny - interpretacji polskiego doświadczenia wielokulturowości, której dokonuje Jan Paweł II. To doświadczenie wielokulturowości i uznanie dla przejawiających się w nim wartości wiąże bowiem papież ze swoim osobistym doświadczeniem, które współkształtuje jego tożsamość, wiąże - w sposób integralny i całościowy także ze swoim doświadczeniem moralnym i doświadczeniem chrześcijańskiej wiary, w których niejako dochodzą do głosu domagające się posłuchu treści normatywne i powinności.

\section{Polskie doświadczenia jako przypadek uniwersalnego dramatu człowieczeństwa}

Dla osób podzielających przekonania antropologiczne i aksjologiczne żywione i propagowane przez Jana Pawła II, jego interpretacja dziedzictwa polskich dziejów - wraz z eksponowanym polskim doświadczeniem wielokulturowości - stała się wiążąca. „Inspirował i porządkował - stwierdza Alfred Marek Wierzbicki - nasze myślenie o Polsce. Jego nauczanie było naznaczone sil-

20 Jan Paweł II: W imię przyszłości kultury. cyt. wyd., s. 61. Następnie papież wyraża swą solidarność z narodami zmagającymi się o kulturową suwerenność: „A kiedy to mówię, myślę równocześnie ze wzruszeniem o kulturze tych ludów starych, które nie ustąpiły w zetknięciu z przeważającymi siłami cywilizacji najeźdźców - i do dzisiaj pozostają dla człowieka źródłem »bycia « człowiekiem w wewnętrznej prawdzie jego człowieczeństwa. I myślę również z podziwem o kulturach tych nowych społeczeństw, tych, które budzą się do życia we wspólnocie własnego narodu - tak jak mój naród budził się do takiego życia dziesięć wieków temu - i które walczą o zachowanie własnej tożsamości i własnych wartości wbrew wpływom i naciskom wzorów narzucanych im z zewnątrz" (tamże, s. 61-62). Zob.: T. Borutka: W życiu i śmierci Totus Tuus. Sylwetka duchowa, działalność pastoralna i dorobek intelektualny papieża Jana Pawła II. Kraków 2010, „Czuwajmy”, s. 163-174. 
nym ładunkiem emocjonalnym, ale pozostawało wolne od sentymentalizmu. Ukazywało piękno cnoty patriotyzmu bez [...] nacjonalistycznego skażenia. Jego oryginalne i zarazem zakorzenione w chrześcijańskiej tradycji myślenie o Polsce poruszało się [...] w personalistycznej orbicie aksjologicznej, [...] poza megalomanią i kompleksami narodowymi" ${ }^{21}$. Doszukując się tak znaczących walorów papieskiej wykładni polskiego etosu, Alfred M. Wierzbicki wyjaśnia też swoistość sposobu widzenia polskości: „Patrzył na Polskę jako na najbliższy mu z racji biografii i zakorzenienia w kulturze przypadek dramatu człowieczeństwa. Nauczanie o Polsce prześwietlał wydobytą ze zbiorowego i wielopokoleniowego doświadczenia prawdą o człowieku"22. Jeśli przyznać słuszność takiemu odczytaniu dokonanej przez Jana Pawła II interpretacji polskiego doświadczenia, to nabiera ona również cech intelektualnie i moralnie doniosłego punktu odniesienia dla rozumienia aksjologicznego i edukacyjnego sensu polskiego doświadczenia wielokulturowości.

Wobec papieża, który z Polski przyszedł do Rzymu - postrzeganego tu jako centrum universum i „oś” świata pełnego różnic - formułowano wszakże wątpliwości, czy nie będzie on reprezentował myślenia zamkniętego na różnice i odmienności. Polskę niektórzy ukazują bowiem jako kraj, którego główne nurty tradycji obarczone są wyłącznie monokulturą katolicko-narodową, jako kraj niemający pożądanego doświadczenia wielokulturowości i tym samym kształtujący postawy zamknięte, wyzbyte otwartości. Nawiązując - aczkolwiek polemicznie - do retoryki tego jednostronnego i radykalnie zawężonego widzenia polskich tradycji, Sławomir Jacek Żurek rozważania o dialogu międzyreligijnym i międzykulturowym jako istotnym elemencie dziedzictwa pontyfikatu Jana Pawła II rozpoczyna pytaniem: „Któż mógł przypuszczać, że

21 A. M. Wierzbicki: Stawialiśmy się społeczeństwem teologicznym. Wstęp. W: tenże: Polska Jana Pawła II. Lublin 2011, KUL, s. 9-10. Następująco wyjaśnione jest dość intrygujące, a użyte przez autora w tytule pojęcie: „Kategoria »społeczeństwa teologicznego« nie ma nic wspólnego z pojęciem państwa wyznaniowego i teokracji. Państwo teokratyczne i państwo laickie, mimo że pierwsze uważane jest za symbol średniowiecza, a drugie za symbol nowoczesności, w istocie są bardzo do siebie podobne: zawsze kłopotliwa jest dla nich ludzka wolność. Dla teokratów liczy się tylko odwieczna wola Boga, natomiast zwolennikom państwa ateistycznego i bezreligijnego sekularyzacja jawi się jako rzeczywistość, poza którą nie ma wyjścia. Społeczeństwo teologiczne to społeczeństwo protagonistów dziejów, które sami tworzą mocą swego samostanowienia” (s. 9). Ks. dr hab. prof. KUL A. M. Wierzbicki jest kierownikiem Katedry Etyki KUL, dyrektorem Instytutu Jana Pawła II KUL i redaktorem naczelnym kwartalnika „Ethos”.

22 Tamże. 
papież z Polski będzie pierwszym biskupem Rzymu, który przekroczy progi synagogi i meczetu oraz spotka się na modlitwie o pokój z przedstawicielami różnych religii w mieście św. Franciszka? Wydarzenia w rzymskiej synagodze, meczecie Omajjadów w Damaszku i w kościele w Asyżu stały się symbolami przełomu, jaki za sprawą Jana Pawła II dokonał się w stosunku Kościoła katolickiego do innych religii. Postawa Papieża spotkała się z niezrozumieniem części katolików, którzy mieli mu za złe »wyprzedawanie« wyjątkowości chrześcijaństwa”. Aby udobitnić wartość otwartej postawy „papieża z Polski”, Sławomir J. Żurek dodaje wzmacniające jego wywód pytanie, które jest też wyrazem solidarności z papieskimi działaniami: „Czyż nie taki zwykle jest los tych, co wyprzedzają swoje czasy?"23.

Podobnie bliski współpracownik papieża, Andrzej Szostek MIC, zwraca uwagę, iż wśród głównych linii pontyfikatu wyraźnie rysują się dążenia ekumeniczne oraz dialog międzyreligijny i międzykulturowy: „Ileż to razy Papież mówił o konieczności oddychania dwoma płucami: Wschodu i Zachodu! Jan Paweł II daleki był oczywiście od irenicznej próby powierzchownego pojednania, ignorującego różnice w wyznawanej wierze. [...] Przekonywał nas jednak, że wysiłek pełnego miłości zrozumienia prawosławnych i protestantów, prowadzony w duchu szukania i poszanowania prawdy, wraz z gotowością pokornego i odważnego wyznania własnych win, [...], jest wolą Chrystusa i stanowi istotny wymóg katolickiej wiary. Dialog ten obejmować musi również niechrześcijan, w pierwszym rzędzie wyznawców judaizmu, naszych starszych braci w wierze. W odniesieniu do nich rachunek sumienia i wyznanie własnych win stają się szczególnie naglące - tym bardziej, że wielu katolików do dziś nie wyzbyło się grzesznego, głęboko niekatolickiego antysemityzmu. Dialog ten wreszcie rozszerzony być powinien na wszystkie wspólnoty religijne, czemu Papież najdobitniej dał wyraz, zapraszając przedstawicieli głównych religii świata do wspólnej modlitwy w Asyżu"24. Zaakcentowane są tu nie tylko

23 S. J. Żurek: Potrzeba „matych Asyży”. „Więź” 2005 nr 5-6, s. 144. Prof. dr hab. S. J. Żurek, literaturoznawca, kierownik Katedry Dydaktyki Literatury i Języka Polskiego oraz kierownik Pracowni Literatury Polsko-Żydowskiej w Instytucie Filologii Polskiej KUL; autor m.in. monografii Zastygłe w polszczyźnie. Szkice o świętach w poezji polsko-żydowskiej dwudziestolecia międzywojennego. Lublin 2011, KUL; Członek Komitetu Episkopatu Polski ds. Dialogu z Judaizmem.

24 A. Szostek MIC: Człowiek droga Kościoła. Główne linie pontyfikatu Jana Pawta II. „Ethos”, numer specjalny 2005, s. 49. Ks. prof. dr hab. A. Szostek, etyk i metaetyk, prowadzi badania m.in. w zakresie myśli etycznej i antropologicznej K. Wojtyły/ Jana Pawła II; były kierownik Katedry Etyki KUL, w latach 1992-1998 prorektor KUL, 
religijne motywacje otwartości papieża na konsekwentny dialog i przezwyciężanie podziałów, ale ukazany jest też etos kształtujący postawy sprzyjające urzeczywistnianiu dążeń ekumenicznych oraz dialogu międzyreligijnego i międzykulturowego.

\section{Polskość: wielość i pluralizm}

W książce „Pamięć i tożsamość. Rozmowy na przełomie tysiącleci”, będącej intelektualnym i duchowym testamentem jej autora, jakby podsumowaniem i syntezą wieloletnich filozoficznych i teologicznych dociekań nad kulturą, wartościami moralnymi i - przede wszystkim - nad osobą ludzką, Jan Paweł II wyraził też zwięźle swe przekonania dotyczące polskiego doświadczenia wielokulturowości: „polskość to w gruncie rzeczy wielość i pluralizm, a nie ciasnota i zamknięcie. Wydaje się jednak, że ten »jagielloński« wymiar polskości, o którym wspomniałem, przestał być, niestety, w naszych czasach czymś oczywistym"25. Wielość i pluralizm, a nie ciasnotę i zamknięcie, prezentuje się tu jako obowiązującą wizję polskości. Wartości, jakimi są wielość i otwartość, trzeba wszakże umieć przyswoić sobie we własnym doświadczeniu egzystencjalnym i moralnym. Uznanie, że o właściwie rozumianej polskości stanowią „wielość i pluralizm, a nie ciasnota i zamknięcie”, określa aksjologiczne zasady kształtowania przekonań i postaw w relacjach międzyludzkich w złożonej sytuacji wielokulturowości.

Myśl o polskości tworzonej z wielości dopełniających się kultur i narodów występuje w różnych wypowiedziach papieża, w których przedstawia i precyzuje swą - modelowo ujętą - wizję polskości: „Polska była zawsze otwarta na wartości kultury innych narodów, przejmowała je, wzbogacała nimi polską obyczajowość i następnie wartości te przekazywała dalej swoim pobratymcom. W tej otwartości i funkcji kulturowego pomostu pomocne było centralne położenie Polski, między Wschodem i Zachodem, Południem i Północą" ${ }^{26}$.

a w latach 1998-2004 rektor KUL. Zob. m.in. A. Szostek: Od samostanowienia do daru z siebie i uczestnictwa. O Karola Wojtyty/Jana Pawła II koncepcji wolności. „Nauka" 2005, nr 3, s. 35-47.

25 Jan Paweł II: Pamięć i tożsamość. Rozmowy na przełomie tysiacleci. cyt. wyd., s. 92.

26 Jan Paweł II: Audiencja z okazji 10-lecia Fundacji Jana Pawta II, Rzym, 26 września 1991; cyt. za: S. Sowiński, R. Zenderowski: Europa droga Kościoła. Jan Pawet II o Europie i europejskości. cyt. wyd., s. 176. 
Pojmowane w ten sposób polskie doświadczenie wielokulturowości zawiera w sobie etyczne przesłanie i jest postrzegane jako potencjał wartości, które także dziś wymagają urzeczywistniania.

Taki syntetyczny opis i zawarta w nim wysoce pozytywna ocena konstytutywnych cech polskości może się jednak spotkać z zarzutem, iż dokonuje się mityzacji polskiej „otwartości na wartości innych kultur” i wyraża się życzeniową projekcję o roli „kulturowego pomostu”, czy wręcz dopuszcza się tu ideologicznego przekłamania i manipulacji, choć w przypadku papieskiej interpretacji jest to świadomy zabieg idealizacji, służący wypracowaniu i ukazaniu pożądanego wzorca polskiej kultury, jako przestrzeni spotkania i dopełniania się różnych kultur; takiego wzorca, który winien przyświecać współczesnej polskiej codzienności. Odium fałszującego rzeczywistość mitu tym łatwiej może wystąpić i wzmóc się, im bardziej będzie się używać wyrażeń sakralnie podniosłych, absolutyzujących dane zjawisko i apodyktycznie brzmiących, które czerpie się z rezerwuaru środków perswazji języka religijnego. Dlatego z daleko posuniętą ostrożnością, bez nakładania będących w obiegu romantycznych schematów myślowych i narodowych kalek światopoglądowych, trzeba podchodzić do programowych i wielokrotnie ponawianych deklaracji papieża o jego kulturowo-religijnej tożsamości, które wyrażał już na początku swego pontyfikatu (w Gnieźnie w 1979 r.): „Papież Jan Paweł II - Słowianin, syn narodu polskiego, czuje, jak głęboko wrastają w glebę historii korzenie, z których on sam razem z wami wyrasta. Ile wieków liczy ta mowa Ducha Świętego, którą on dzisiaj sam przemawia i z watykańskiego wzgórza świętego Piotra, i tutaj w Gnieźnie ze Wzgórza Lecha, i w Krakowie z wyżyn Wawelu"27. Taką metaforyczną autoprezentację, nawiązującą do poetyckich wizji i sformułowaną wręcz profetycznie, mającą też funkcje performatywne, gdyż współkształtującą papieską tożsamość i jej społeczny odbiór, acz obarczoną dużą dozą wieloznaczności, można konkretyzować w różny sposób, akcentując różne treści; można m.in. zwracać uwagę na to, jak postrzega się własne korzenie, które „głęboko wrastają w glebę historii” i co wartościowego z tej gleby ma wyrastać. W wypowiedziach papieża napotyka się częstokroć łączenie jakiegoś - poddanego idealizacji i pozytywnie ocenianego - aspektu polskich dziejów z kształtowaniem się jego tożsamości: „W odróżnieniu od krajów Zachodu, Polska pozostała państwem, w którym nie było

27 Jan Paweł II: Ojczyzna. Warszawa 2008, New Media Concept, s. 34. Zob. też: T. Borutka: Wizja katolicyzmu polskiego w świetle pielgrzymek Jana Pawła II do Ojczy$z n y$. Bielsko-Biała 1997, Instytut Teologiczny im. św. Jana Kantego, s. 124-133. 
stosów. Afirmacja wolności w odniesieniu do tego, co najbardziej wewnętrzne w człowieku, należy do dziedzictwa duchowego papieża z Polski"28. Akceptacja antropologicznych założeń etycznego imperatywu afirmacji wolności w odniesieniu do tego, co najbardziej wewnętrzne w człowieku i uznanie moralnej powinności respektowania tego imperatywu, zespala się tu z własnym „dziedzictwem duchowym papieża z Polski”, z jego tożsamością uformowaną dzięki przyswojeniu sobie aksjologicznych treści płynących z - odpowiednio interpretowanego - doświadczenia polskich dziejów.

Dokonując refleksji nad papieską myślą o polskości, należy wszakże respektować przestrogi przed skłonnością do mityzacji polskich dziejów i promowaniem ich mitologicznej wizji, mogącej pełnić rolę narodowego opium. Dość zdecydowanie - głosząc rygorystyczne sądy - do takiego niebezpieczeństwa podszedł Tischner i uczynił to w 1978 roku, bezpośrednio po wyborze Wojtyły na papieski urząd. Oddając panujące wówczas nastroje, wzywał do wykształcenia i zachowania krytycznego dystansu względem własnego nastawienia i sposobu widzenia: „Patrząc pamiętnego dnia w ekran telewizyjny, czuliśmy (w każdym razie wielu to czuło), jak wylewa się z nas nasza romantyczna podświadomość. »Słowiański papież«. Tylko romantycy potrafią mieć prawdziwe marzenia. [...] Papież wyrósł z nas, z naszego krajobrazu, z naszego dramatu, z dialogu z nami. Oto teraz staje na piedestale jako sumienie świata. [...] Widzimy »słowiańskiego papieża « poprzez pryzmat tekstów romantycznych i naszej romantycznej podświadomości jako spełnienie romantycznej racji stanu, która była, jest i będzie naszą chlubą"29. Trudności w polskiej recepcji „słowiańskiego papieża” powodowane są w dużej mierze brakiem dojrzałej myśli, będącej w stanie trafnie rozeznać sytuację, z którą ma się do czynienia. „Powiem po prostu - stwierdza Tischner: daliśmy światu papieża, ale nasza noosfera, nasz logos są puste. Gdy mówimy, mówimy na ogół to, co powiedzieli inni” ${ }^{30}$. Intelektualna pustka wzmaga

\section{Tamże, s. 62.}

29 J. Tischner: Po wyborze Papieża. (1978) W: tenże: Idac przez puste Błonia. cyt. wyd., s. 6.

30 Tamże, s. 7. „Nasza religijność jest religijnością wydarzeniową, religijnością zogniskowaną wokół wydarzeń i ich dziejowych reperkusji, a nie wokół trwających prądów myślowych, inspirującą te prądy i żyjącą w nich. Ojciec Kolbe to wielkie wydarzenie. Ale tylko wydarzenie. Nie towarzyszy mu żadna wielka myśl filozoficzna i teologiczna o człowieku, o ludzkim etosie, o sposobie naprawy rzeczy, które są nam wspólne" (tamże). 
ryzyko niepożądanej mityzacji polskich dziejów w kontekście wyjątkowego wydarzenia, jakim jest pontyfikat papieża z Polski i wiązane z nim - także w wymiarze społeczno-politycznym - nadzieje. Dlatego Tischner, przeciwstawiając się dominującym nastrojom, przestrzega, iż jakby wymuszany przez polskie dzieje, zwłaszcza przez niepowodzenia i klęski, „jednostronny kult moralności, moralności zwyciężonych, także może usypiać. A wtedy - fakt »słowiańskiego papieża « może działać jak opium"31. Współtworzenie polskiej noosfery i rozwijanie logosu, który pozwala rozumieć polskie dzieje, stało się wyzwaniem także dla Jana Pawła II, aby jego postać „słowiańskiego papieża” nie działała jak opium. Wydaje się, iż rozwijana przez papieża interpretacja polskiego doświadczenia wielokulturowości budzi z „narodowej drzemki” wyprowadza z oparów ideologicznej iluzji o kulturowej jednorodności polskiego etnosu. Mimo to nie da się wykluczyć, iż na niektórych - ze względu na ich nastawienie ideowe i emocje - „słowiański papież” i jego słowa o walorach polskości działają jak opium, usypiają. Tym bardziej - mając na względzie teorię i praktykę edukacji międzykulturowej - należy rozeznać treści zawarte w papieskiej wizji polskości, w której dominuje pozytywnie oceniana wielość i pluralizm, a neguje się ciasnotę i postawy zamknięte.

Spotkanie różnych kultur i tradycji religijnych, do którego dochodziło na terenach Rzeczypospolitej - określanej jako „Rzeczypospolita wielu narodów" - jest jednym z głównych tematów przemówienia Jana Pawła II w - będącej niejako skrawkiem Archidiecezji Lwowskiej pozostającym w polskich granicach - protokatedrze lubaczowskiej (Lubaczów, 2 VI 1991): „Kiedy król Kazimierz Wielki ustanawiał na tych ziemiach biskupstwo łacińskie, które później z Halicza zostało przeniesione do Lwowa, istniało tu już biskupstwo rytu bizantyńsko-słowiańskiego związane z metropolią w Kijowie. [...] znajdujemy się na obszarze spotkania dwóch tradycji chrześcijańskich i dwóch kultur: bizantyńskiej, związanej z Rusią, i łacińskiej, związanej z Polską, naprzód jeszcze piastowską, później jagiellońską. To, co rozwinęło się z kolei w Rzeczypospolitą wielu narodów, ma właśnie w metropolii lwowskiej swój punkt odniesienia, podobnie jak historyczne dziedzictwo Piastów miało swój punkt odniesienia w metropolii gnieźnieńskiej" ${ }^{32}$. Papież wydobywa i akcentuje pozytywnie oceniane postawy i zdarzenia, które miały miejsce w obszarze pogranicza i spotkania kultur: „na przestrzeni wielu wieków dzieje te były

31 Tamże, s. 8.

32 Jan Paweł II o dziejach Polski. Wybór i oprac. A. Zwoliński. Radom 2004, POLWEN, s. 47. 
naznaczone porozumieniem, przymierzem i unią, współdziałaniem i współtworzeniem - przy całej odrębności tych przecież zróżnicowanych członków wielkiej Rzeczypospolitej. Wspólnym dorobkiem wszystkich - pomimo feudalnych struktur państwa i społeczeństwa - był duch tolerancji i wolności wewnętrznej. [...] w tym wielonarodowym i wielowyznaniowym organizmie pozostały w mocy słowa ostatniego Jagiellona: nie jestem panem waszych sumień" ${ }^{33}$. To aksjologiczne dziedzictwo wspólnego doświadczania wielokulturowości ma - wedle papieża - nie tylko należeć do minionych dziejów i zamkniętej przeszłości, ale powinno zachować aktualność w kontekście obecnych przemian i wyzwań: „To wszystko trzeba mieć przed oczyma także [...] w perspektywie trzeciego tysiąclecia po Chrystusie. Chodzi tu bowiem o wartości, które muszą przetrwać w życiu każdego z narodów dawnej Rzeczypospolitej. [...] Nie możemy zapomnieć, że te wartości i zasady były kiedyś wspólnie tworzone. Stanowią więc dla każdego z naszych narodów dorobek i własność równocześnie rodzimą, własną, a przecież wspólną" ${ }^{34}$. Ponownie kwestia zespolenia partykularności i uniwersalności kultury („własności równocześnie rodzimej, a przecież wspólnej") występuje w interpretacji polskiego doświadczenia wielokulturowości.

Na eksponowany tu proces spotkania dwóch kultur: bizantyńskiej i łacińskiej, zwraca się uwagę - już od początku pontyfikatu - w teologicznych komentarzach, przyjmując, iż w tym procesie formowała się także swoista „tożsamość pogranicza” Jana Pawła II, który jako „Polak, Słowianin, będący w zasięgu kultury łacińskiej i helleńskiej, na granicy Wschodu i Zachodu, dziedzic dwóch wielkich tradycji duchowych, staje się żywym zaczynem jedności europejskiej"35. Postać papieża wpisuje się - jako czynnik aktywny i sprawczy - w te procesy i dążenia, które są przedmiotem jego namysłu.

Doświadczenie wielokulturowości i kształtowanie postaw umożliwiających spotkanie różnych kultur stanowią dla Jana Pawła II także klucz do interpretacji - duchowo bliskiej mu - postaci królowej Jadwigi, „której dziedzictwo andegaweńskie wywodzi się z Francji, aby w swoich rodowych rozgałęzieniach trafić do królestwa Neapolu na południu Włoch, a równocześnie na Węgry. Jadwiga - córka Ludwika, króla Węgier i Polski, a wnuczka Elżbiety Łokietkówny. Jadwiga, która z kolei otwarła nasze dzieje na Wschód”.

33 Tamże.

34 Tamże, s. 48.

35 J. Chelini: Powrót profetyzmu: Jan Pawet II w Polsce. „Communio”. Międzynarodowy Przegląd Teologiczny 1998, nr 5, s. 26. 
Zarysowanie tych historycznych koligacji i dokonań królowej Jadwigi prowadzi papieża do ich odczytania w aktualnym kontekście: „Wszystko to ma swą wymowę bardzo współczesną, kiedy stoimy wobec imperatywu Europy bardziej pojednanej, zbudowanej na poszanowaniu praw człowieka i praw narodów" ${ }^{36}$. Te prawa powinny być respektowane, jeśli dążenie do jedności ma być aksjologicznie usprawiedliwione i nie ma skutkować wymuszaniem ujednolicenia.

Rozpatrując promowaną przez Jana Pawła II interpretację polskości, Wierzbicki zwraca uwagę na dokonujące się w niej przewartościowania: „Żyjąc ethosem polskości jagiellońskiej, Papież Polak przezwycięża wąskie rozumienie polskości i polskiego patriotyzmu, które znalazło wyraz w stereotypie Polaka katolika, rozpowszechnionym przez [...] nurty myśli narodowej. Trzeba jednak podkreślić, że to doniosłe przewartościowanie sensu polskości i patriotyzmu nie dokonuje się u Jana Pawła II w kategoriach myślenia politycznego, lecz poprzez ich istotne przezwyciężenie dzięki myśleniu o narodzie w kategoriach religijnych. Nie bez znaczenia przy tym pozostaje integracja pozytywnej oceny patriotyzmu z podejściem ekumenicznym i z duchem dialogu międzyreligijnego, która pozwala człowiekowi odczytywać pełniejszą prawdę o innych"37. Czy jednak prezentowane przez Jana Pawła II podejście do rozpatrywanych tu kwestii jest podzielane przez wszystkich jego rodaków i współwyznawców z równą mocą, jak przez Wierzbickiego?

W związku z podejmowanym tu zagadnieniem papieskiej interpretacji polskiego doświadczenia wielokulturowości warto przywołać fragmenty przyjacielskiej korespondencji Stefana Swieżawskiego z Janem Pawłem II, bowiem znali się oni, dyskutowali i przyjaźnili blisko pięćdziesiąt lat. W korespondencji Swieżawski konsekwentnie podejmuje m.in. sprawę wypracowania i promocji pożądanego sposobu rozumienia polskiej kultury oraz docenie-

36 Jan Paweł II: Niech się zjednocza w naszej świadomości dwie kobiece postaci: królowa i stużaca. Homilia wygłoszona na Rynku Krakowskim podczas Mszy św. beatyfikacyjnej Sługi Bożej Anieli Salawy, 13 sierpnia 1991. W: Jan Paweł II: Otrzymaliście ducha przybrania za synów. Drugi etap czwartej wizyty duszpasterskiej w Polsce 13-16 sierpnia 1991 roku. Watykan 1992, Libreria Editrice Vaticana, s. 22-23.

37 A. M. Wierzbicki: Papież, który żyt Polska. Jana Pawła II interpretacja polskości. W: tenże: Polska Jana Pawła II. cyt. wyd., s. 38; autor ten dopowiada: „Zasługą Jana Pawła II jest oczyszczenie patriotyzmu z uwikłania w ideologie nacjonalistyczne wyrosłe na gruncie myślenia areligijnego, a nawet antychrześcijańskiego, uwikłania, które [...] prowadziło do politycznej instrumentalizacji przekonań religijnych" (tamże). Zob. też: J. Salij OP: Patriotyzm dzisiaj. Poznań 2005, W drodze. 
nia walorów doświadczenia wielokulturowości. W liście datowanym na $16 \mathrm{X}$ 1989 roku wskazywał on na niepokojące zjawiska w polskiej kulturze religijnej: (1) „Orientacja utylitarnie duszpasterska prowadzi do zaniku życiu duchowego”. (2) Formacja osób duchownych częstokroć przebiega niewłaściwie, gdyż są oni „wychowywani w strachu: boją się swoich wychowawców, a potem swoich przełożonych". (3) Wśród błędnych postaw duchownych wymienia: „Brak otwarcia wobec każdego człowieka; brak zrozumienia w praktyce, że i w Polsce są nie tylko katolicy, że są inne wyznania i liczni niewierzący, których trzeba może bardziej kochać i ochraniać niż tzw. przekonanych katolików”. (4) Wśród patologicznych zachowań szczególnie groźne są: „Ciasnota »endekoidalna«, szowinizm i triumfalizm narodowy, połączone z podskórnym antysemityzmem (bardzo - niestety - u nas rozpowszechnionym) i kultem dla »środków bogatych « charakteryzuje mentalność wielu duchownych. Moralność ta jest antytezą tego wszystkiego, co wprowadził ostatni Sobór”38. W odpowiedzi Jan Paweł II pisze: „Podzielam nie tylko troski (o społeczeństwo), ale także i obawy (zwłaszcza o duchowieństwo)" ${ }^{39}$. Wzajemne zrozumienie obu autorów listów oraz ich wspólna troska i wspólne obawy „dają do myślenia”. W liście z 3 października 1990 roku Swieżawski ponownie podejmuje sprawę "sprzeniewierzenia [się] wytycznym ostatniego Soboru”. Wedle jego rozeznania w parafiach często odbywają się „imprezy społeczno-narodowe”, na których „pożywkę znajduje bigoteria, a nie solidne życie sakrametalno-modlitewne”. Dzieli się niepokojącym go odczuciem: „Coraz częściej słyszy się ze strony ludzi głęboko wierzących i głęboko oddanych Kościołowi, że ten klimat »triumfalistycznego i bogatego klerykalizmu« staje się u nas tak odpychający, że czasem trudno powstrzymać się od głębokiej niechęci i krytyki. W Polsce dochodzi do tego nasilający się element nacjonalistyczny. Aż serce się kraje, jak często wspaniała tradycja naszego, »jagiellońskiego patriotyzmu « - otwartego, pluralistycznego i tolerancyjnego - zanika na rzecz ciasnych, egoistycznych postaw szowinistycznych”. Wytknąwszy te słabości polskiego katolicyzmu, który zaprzepaszcza własne tradycje i wzorce otwartego patriotyzmu, przyznaje: „Gdybym nie miał szczęścia poznania [...] wspaniałego katolicyzmu [...] - dzisiejszy styl katolicyzmu polskiego byłby dla mnie raczej

38 A. Federowicz, T. Federowicz, S. Swieżawski, K. Wojtyła: Pełny wymiar. Listy przyjaciót. Opracował A. Dobrowolski. Tarnów 2002, „Biblos”, s. 319-320. Zob. też: A. Boniecki: Listy przyjaciót. „Tygodnik Powszechny” 2002 (17 XI), nr 46, s. 13.

39 Tamże, s. 321. 
odpychający" ${ }^{\text {. }}$. W odpowiedzi Jan Paweł II określa te słowa jako „rachunek sumienia” dotyczący „Kościoła (i społeczeństwa) posoborowego AD 1990”, którego treść obiecuje przekazać właściwym „adresatom” ${ }^{\text {. }}$. W kolejnym z listów Swieżawski przestrzega przed zniweczeniem polskiego doświadczenia wielokulturowości: „Widzę ogromne niebezpieczeństwo sojuszu władz kościelnych z prawicą, bo to jak gdyby w nasze czasy przeniesione przymierze Kościoła z Tronem! Wiemy dobrze, jak opłakane były i są tego skutki. Martwi mnie też bardzo forowany przez koła prawicowe model polityczno-kulturalny Polski. Jest to skrzyżowanie ideałów Sienkiewiczowskich z kontrreformatorskimi. A przecież nie XVII wiek i ówczesny sarmatyzm, lecz model Polski jagiellońskiej powinien nas inspirować. Taki jest testament krakowskiej szkoły prawniczej z XV w. i świętości życia królowej Jadwigi. O ten jagielloński ideał Polski walczę, jak mogę, ale właśnie to zwalczają ex-komuniści i skrajna prawica we wspólnym szyku" (Warszawa, 6 VI 1995). Poglądy wyrażane w przyjacielskiej korespondencji uwidaczniają bliską więź ideową między autorami listów. Ostrość przywołanych sądów Swieżawskiego jest koniecznym elementem rzetelnej debaty o statusie i urzeczywistnianiu wartości istotnych dla uczestników debaty o trafną interpretację polskiego dziedzictwa kulturowego i właściwy kształt polskiej tożsamości.

Refleksje o polskim doświadczeniu wielokulturowości Jan Paweł II przywołał również w książce „Przekroczyć próg nadziei”, gdy wypowiadał się o ekumenizmie $\mathrm{w}$ rozmowie $\mathrm{z}$ Victorio Messorim. Pytania o ekumenizm włoski dziennikarz formułuje w sposób odpowiedni dla jego ideowych przekonań, akcentując rozczarowania i pogłębiające się przepaści między wyznaniami ${ }^{42}$; sugerując, iż ekumenizm niezbyt wiele daje z tego, co obiecuje, a bywa bardzo ryzykownym przedsięwzięciem. Na przyjęcie takiego toku myślenia, na który naprowadza Messori, nie godzi się jednakże Jan Paweł II. Dążenia ekumeniczne mają być bowiem czymś wręcz oczywistym i mają być nakazem sumienia, zwłaszcza dla kogoś, kto świadomie uznaje za własne polskie doświadczenia w tym zakresie. Papież zaczyna odpowiedź od zmiany narzucanego mu podejścia: „Zanim będziemy mówić o rozczarowaniach, skoncentrujmy się na tym, przez co niewątpliwie Sobór Watykański II otworzył drogę ekumeniczną

40 Tamże, s. 324. Na te (strukturalne wręcz) błędy zwracał też uwagę m.in. ks. J. Tischner.

41 Tamże, s. 325.

42 Jan Paweł II: Przekroczyć próg nadziei. Jan Paweł II odpowiada na pytania Vittoria Messoriego. Lublin 1994, KUL, s. 116. 
w dziejach Kościoła”. I solidaryzuje się z soborowym otwarciem na ekumenizm: „Dla mnie - stwierdza papież - ta droga była bardzo bliska. Wywodzę się bowiem z narodu, który uważny bywa za przede wszystkim katolicki, ale który ma swoje ekumeniczne tradycje" ${ }^{33}$. Swą wizję ekumenizmu Jan Paweł II w dużej mierze opiera na interpretacji polskiej historii. Rozpatrując warunki ekumenizmu, na plan pierwszy wysuwa „wzajemny szacunek” i uważa, że jest on „wstępnym warunkiem autentycznego ekumenizmu”44. Doniosłość wzajemnego szacunku w autentycznym ekumenizmie jest potwierdzona - jak to wyraża papież - w doświadczeniu dziejów kraju, z którego wyszedł; kraju, w którym „wydarzenia historyczne, uformowały [...] społeczeństwo wielowyznaniowe i wielonarodowe, nacechowane wielką tolerancją" ${ }^{45}$. Dopełnia się tu wielość wyznań, wielość nacji i tolerancyjna polskość. Papież przywołuje przykłady: „W czasach kiedy na Zachodzie Europy toczyły się procesy i płonęły stosy dla heretyków, ostatni król Polski z rodu Jagiellonów dał świadectwo tolerancji w słowach: Nie jestem królem waszych sumień" ${ }^{46}$. Zarysowując historię i koncepcję ekumenizmu, Jan Paweł II wychodzi z polskich dziejów i - jako etyk - odnosi się do podstawowej rzeczywistości człowieka, rzeczywistości sumienia, która nie ma nad sobą zewnętrznego króla. Jan Paweł II przedstawia następujący obraz polskiej tradycji wielokulturowości: „Przez wieki swojej tysiącletniej historii, Polska była państwem wielu narodów i wielu wyznań chrześcijańskich i nie tylko chrześcijańskich. Tradycja ta sprawiła i chyba nadal sprawia, że właściwa umysłowości Polaków jest raczej tolerancja i otwartość na ludzi inaczej myślących, mówiących innymi językami, czy też inaczej wierzących, inaczej modlących się [...]"47.

Dla zrozumienia stanowiska Jana Pawła II pouczający wydaje się przebieg -przywołanej powyżej - dyskusji z Messorim, który rozmawiając z papieżem, zadając mu pytania z tezą, usiłuje jakby skierować rozmówcę na obrany przez siebie tor dyskursu. Natomiast Jan Paweł II „przestawia zwrotnicę” i kieruje rozmowę na inny tor, mówiąc o polskim doświadczeniu historycz-

\footnotetext{
43 Tamże, s. 116.

44 Tamże, s. 122.

45 Tamże.

46 Tamże.

47 Tamże, s. 116. „Przez dzieje Polski - dodaje Jan Paweł II - przebiegają też konkretne inicjatywy unijne: Unia Brzeska, jako początek Kościoła wschodniego, Kościoła katolickiego obrządku bizantyjsko-ukraińskiego, który był przede wszystkim Kościołem ludności ruskiej i białoruskiej" (tamże).
} 
nym, w którym ekumenizm ma być głęboko zakorzeniony, gdyż Polska była wielonarodowa, wielowyznaniowa i cechowała się tolerancją. Dwa razy z naciskiem powtarza te sformułowania, aby sobie i innym wyraźnie uświadomić treści i sens polskiego doświadczenia ekumenicznego, które uznaje za konstytutywny element własnej tożsamości.

W czasie spotkania ze wspólnotą Kościoła ewangelicko-augsburskiego w kościele ewangelickim w Skoczowie (22 V 1995) Jan Paweł II prezentuje bliskie mu - polskie tradycje ekumeniczne: „Mówiąc o ekumenizmie, trudno nie wspomnieć, iż Polska ma bogate tradycje, gdy idzie o dialog Kościoła katolickiego zarówno z Kościołem prawosławnym, jak i z Kościołami i Wspólnotami reformowanymi. Niech mi będzie wolno przywołać na pamięć jeden tylko przykład. Kamieniem milowym na szlaku ekumenicznym było z pewnością Colloquium charitativum, to znaczy spotkanie przedstawicieli katolików oraz luteran i kalwinistów z całej Europy, zwołane do Torunia w roku 1645 przez króla polskiego Władysława IV. [...] Chociaż nie przyniosło ono spodziewanych rezultatów, to jednak posiadało, jak na owe czasy, charakter pionierski i było dla Europy podzielonej konfliktami religijnymi jakimś ważnym przypomnieniem, że droga do jedności to droga dialogu, a nie przemocy - jak wówczas niestety wielu uważało. Idea wolności sumienia z trudem dojrzewała w świadomości europejskiej. Potrzeba było wielu ofiar [...], aby zdobyła sobie ostateczne prawo obywatelstwa"48. Papież przypomina też los ofiar religijnych sporów, walk i zbrodni w nowożytnej Europie: „społeczeństwa Europy rządziły się nieludzką zasadą: cuius regio eius religio, w imię której to zasady panujący - gwałcąc podstawowe prawa sumienia - narzucali przemocą własne przekonania religijne swoim poddanym" ${ }^{49}$. Uznanie wartości dialogu ekumenicznego i respektowanie prawa do wolności sumienia zostają tu wysunięte na pierwszy plan. To w ich perspektywie, jako pożądane albo jako niedopuszczalne, ocenia się dawniej praktykowane zachowania i żywione przekonania w sprawach wiary religijnej.

Uniwersalizacja polskich tradycji i zawarty w nich wymiar powszechności ma być jak najbardziej osobistym doświadczeniem Jana Pawła II: „Myślę, że ta ojczyzna, jej dzieje, dzieje Kościoła, dzieje narodu, w jakiś wyjątkowy sposób przygotowały mnie do tego, ażeby być solidarnym z różnymi narodami świata. [...] I jest mi łatwo poprzez to właśnie dziedzictwo odnaleźć

48 Jan Pawet II o dziejach Polski. cyt. wyd., s. 91-92.

49 Jan Paweł II: Być człowiekiem sumienia. Bielsko-Biała 2005, Kuria Diecezji Bielsko-Żywieckiej, s. 10. 
solidarność szczególną z tymi ludźmi, a także z tymi narodami, które cierpią, które [...] są w jakikolwiek sposób dyskryminowane, upośledzone, pozbawione wolności, [...], jest mi łatwo natychmiast być z nimi wszystkimi, ponieważ nauczyłem się od maleńkości być z narodem, który miał niełatwe dzieje i ma także niełatwą współczesność" ${ }^{50}$. To, co z polskiego dziedzictwa kształtowało papieską tożsamość, miało wydatnie wzmacniać otwartość i bliskość w relacjach z innymi: „W czasie tych podróży przekonałem się, że z moim doświadczeniem historii ojczyzny, z moim narastającym doświadczeniem wartości narodu nie byłem wcale obcy ludziom, których spotkałem. Wręcz przeciwnie, doświadczenie mojej ojczyzny bardzo mi ułatwiło spotykanie się z ludźmi i narodami na wszystkich kontynentach" ${ }^{1}$. Wyniesione z historii własnego narodu doświadczenia (także doświadczenia aksjologiczne) oraz nieustannie formowana i pogłębiana w oparciu o nie własna tożsamość postrzegane są przez papieża jako pozytywny i wręcz niezbędny zaczyn owocnych spotkań z ludźmi innych tradycji i kultur.

Przemawiając do Polaków w latach 80. XX wieku, Jan Paweł II stwierdzał: "Jestem niesłychanie wdzięczny mojemu narodowi, polskiej szkole, polskiemu uniwersytetowi, polskiemu Kościołowi, polskim doświadczeniom historycznym, że mogę na spotkanie tych wszystkich współczesnych doświadczeń ludzkości wychodzić tak adekwatnie przygotowany"52. W tej wypowiedzi o sensie i dziedzictwie polskich dziejów pojawiają się dwie kluczowe kategorie, odgrywające istotną rolę w myśli Wojtyły/Jana Pawła II: kategoria wdzięczności i kategoria doświadczenia. To są kategorie, które Wojtyła, jako etyk i filozof uprawiający antropologię, poddawał analizie. Na pojęcie wdzięczności zwracał uwagę, rozwijając koncepcję daru. Zastanawiając się nad punktem wyjścia etyki, kładł akcent na rolę doświadczenia w etyce ${ }^{53}$. Dokonując rzetelnego oglądu danych doświadczenia, człowiek może wyczytać

50 Jan Paweł II: Ojczyzna. cyt. wyd., s. 68-69. Zob. K. Wolsza: Prawa człowieka - lista życzeń czy wyraz afirmacji osoby? W: K. Wolsza (red.): Wspótczesne dylematy etyczne. Opole 2005, UO, s. 17-38.

51 Tamże, s. 69.

52 Jan Paweł II: Autobiografia. Wybrała i ułożyła J. Kiljańczyk-Zięba. Kraków 2003, WL, s. 125. Zob. też: R. Dzwonkowski: Papież Jan Pawet II a Polonia i Polacy za granicq. „Ethos” 2003, nr 3-4, s. 227-244.

53 K. Wojtyła: Problem doświadczenia w etyce. „Roczniki Filozoficzne” 1969, z. 2, s. 5-24. Zob. też: T. Styczeń SDS: Doświadczenie człowieka i świadczenie człowiekowi. „Znak” 1980 nr 3, s. 263-274; A. Szostek MIC: Doświadczenie człowieka i moralności w ujęciu kardynata Karola Wojtyty. „Znak” 1980 nr 3, s. 275-289. 
z nich, kim rzeczywiście jest i jakie są jego powinności. Bez uwzględnienia pojęcia doświadczenia nie da się zrozumieć dociekań Wojtyły i Jana Pawła II, gdyż w punkcie wyjścia przyjmuje się w nich, że człowiek jest dany i zadany sobie w doświadczeniu. Takie podejście dotyczy też analiz doświadczenia polskości. A to właśnie zreflektowane doświadczenie polskości i polskiej wielokulturowości, jak mówi papież, otwarło go na wejście we współczesne doświadczenie zróżnicowanej ludzkości.

W przytoczonej powyżej wypowiedzi uwagę zwraca, iż papież wyraża zdecydowanie wdzięczność za polskie doświadczenia, które były i są jego udziałem: „Jestem niesłychanie wdzięczny polskim doświadczeniom historycznym, że mogę na spotkanie [...] współczesnych doświadczeń ludzkości wychodzić tak adekwatnie przygotowanym". A przecież te polskie doświadczenia - także w ich całokształcie - częstokroć bardziej się kojarzą z jakimś przeklętym losem, z jakimś fatum niepowodzeń. Wiele spośród ujęć polskich dziejów i wiele treści w polskiej historiozofii bywa bliskich myśli istotowo „pogańskiej”, fatalistycznej, manichejskiej, gdyż wykazuje się, iż nad polskim losem ciąży fatum nieprzezwyciężalnych nieszczęść geopolitycznych lub fatum nieszczęść własnych wad i nietrafnych decyzji narodowych. W papieskiej wypowiedzi jest wszakże świadomie użyte i wyeksponowane słowo „wdzięczność”. Jest ono tu o tyle zasadnie użyte, iż na sens dziejów polskich spogląda papież „w świetle” nadziei chrześcijańskiej. To rzadki przypadek, gdy w historiozoficznym opisie polskich losów nie manifestuje się narodowych żalów, ale przejawia się chęć zrozumienia pozytywnego sensu i wartości polskiego doświadczenia, a także konsekwentnie jest wyrażana wdzięczność za to doświadczenie.

Zwracając się do Polaków w latach 80. ubiegłego wieku, Jan Paweł II rozwijał refleksję o wartości polskiego doświadczenia i wdzięczności za uczestnictwo w nim: „myślę, że [polskie doświadczenie] jest przede wszystkim dziełem Opatrzności, która przygotowała nasz naród, przez różne doświadczenia do tego momentu, w którym właśnie Polak będzie najlepiej [...] duchowo przygotowany [...], nawet przez wielkie cierpienia swojego narodu, do tego, ażeby zrozumieć współczesny moment świata”54. Ważąc słowa, wyjaśniał: „Ja tego nie mówię w poczuciu żadnym innym, tylko w poczuciu wdzięczności i dla Opatrzności, i dla mojego narodu - dla historii tego narodu, dla jego duchowych dziejów, dla jego wielkich cierpień, ponieważ czuję się synem i dziedzicem tego wszystkiego" ${ }^{55}$.

54 Jan Paweł II: Autobiografia. cyt. wyd., s. 125.

55 Tamże. 
Występująca tu kategoria doświadczenia polskiego nie jest zawężeniem cenionych przez papieża doświadczeń wyłącznie do jednego narodowego punktu widzenia, ale zawiera w sobie współczynnik uniwersalistyczny, dotyczy bowiem przede wszystkim doświadczenia człowieka, który - jako człowiek - jest Polakiem. „Wydobyć z Polaka człowieka” - to przekonanie wypowiedziane przez Cypriana K. Norwida na swój sposób wyraża Jan Paweł II; przy czym bliskość do myśli Norwida była istotnym elementem papieskiej formacji intelektualnej i duchowej. Ze swoistych polskich doświadczeń należy wydobyć uniwersalne doświadczenie człowieka. Co więcej, papież stwierdza, że dzięki temu polskiemu doświadczeniu on - jako Polak - jest odpowiednio ukształtowany i duchowo przygotowany do tego, aby zrozumieć współcześnie dokonujące się przemiany. W zetknięciu z takimi tezami może pojawić się zarzut o polski „szowinizm” lub swoiste „nawiedzenie narodowe”. Dlatego Jan Paweł II zastrzega się, iż mówi o polskości w poczuciu wdzięczności, a nie w poczuciu narodowej buty. Kategoria wdzięczności jest istotna, aby uchwycić intuicję Jana Pawła II. Jeśli ktoś nie ma w sobie poczucia wdzięczności, ale jego nastawienie wobec ludzi determinuje duch przeklinania własnego losu i innych jako sprawców tego losu, jeśli ktoś nie ma w sobie wdzięczności, ale ma ducha niechęci do innych, to nie będzie podzielał papieskiej intuicji. W imię wierności własnemu doświadczeniu papież czuje powinność okazania wdzięczności, za dar zawarty w tym doświadczeniu dziejowym, którego on czuje się dziedzicem. Jest to taki dar, do którego trzeba dorosnąć, aby się z nim zmierzyć i umiejętnie go przyjąć.

W przywołanej książce „Pamięć i tożsamość” Jan Paweł II, przedstawiając wypracowane przez siebie rozumienie polskości i prowadząc jakby medytację nad polskością, wysuwa hipotezę: „Historycznie polskość ma za sobą bardzo ciekawą ewolucję”, której „nie przeszła prawdopodobnie żadna inna narodowość w Europie" ${ }^{56}$. Prezentując syntezę swej interpretacji polskości, Jan Paweł II wyznacza główne momenty tej ewolucji: „Naprzód w okresie zrastania się plemion Polan, Wiślan i innych to polskość piastowska była elementem jednoczącym. Potem przez pięć wieków była to polskość epoki jagiellońskiej. Pozwoliła ona na utworzenie Rzeczypospolitej wielu narodów, wielu kultur, wielu religii. Wszyscy Polacy nosili w sobie tę religijną i narodową różnorodność" ${ }^{57}$. Interpretując polskie doświadczenie wielości narodów,

56 Jan Paweł II: Pamięć i tożsamość. Rozmowy na przełomie tysiacleci. cyt. wyd., s. 91.

57 Tamże. 
kultur i religii, papież - używszy w swej narracji aż trzy razy słowa „wielu” - stwierdza, że wszyscy Polacy noszą w sobie - w wewnętrznym, duchowym doświadczeniu, które określa ich tożsamość - taką religijną i narodową różnorodność. Zarysowuje się tu oparte na uczestnictwie w wielości kultur kryterium polskości. Można nawet zastanawiać się, czy jeśli ktoś temu kryterium nie sprosta, bo ze względu na żywione przez siebie przeświadczenia pozbawia się pozytywnie rozumianego doświadczenia wielokulturowości, to - idąc za wskazaniami Jana Pawła II - trzeba uznać, iż nie przysługuje mu miano Polaka, który dziedziczy tradycje Rzeczypospolitej wielu narodów, wielu kultur, wielu religii? W tym - nieco prowokacyjnie - postawionym pytaniu nie chodzi o to, aby dokonując rozstrzygnięć i udzielając odpowiedzi kogoś wykluczać, gdyż służyć ma ono przede wszystkim pobudzaniu refleksji nad papieską wizją religijnej i narodowej różnorodności, wizją postulującą przyjęcie pewnych rozwiązań w zakresie ładu aksjonormatywnego.

Dziedzictwo dziejów kultury kształtujące osobową tożsamość wraz ze swą duchową genealogią i jej koligacjami ukazuje Jan Paweł II w sposób przypominający nanoszone na mapę kręgi kulturowych wpływów rozchodzących się z Krakowa jako centrum Małopolski, które przenikają się z kręgami wpływów dochodzących do Krakowa: „Sam pochodzę z Małopolski, z terenu dawnych Wiślan silnie związanych z Krakowem, ale nawet i tu w Małopolsce, może nawet w Krakowie bardziej niż gdziekolwiek, czuło się bliskość Wilna, Lwowa i Wschodu"58. Eksponuje tu papież bliskość tradycji Wschodu, a także w postaci św. Wojciecha upatruje w jakiejś mierze spadkobiercę tradycji wschodniej, tradycji cyrylo-metodiańskiej ${ }^{59}$. To współgra z często przywo-

58 Tamże, s. 91-92. Można nadmienić, iż w kronikach o Cyrylu i Metodym znajduje się krótki zapis o księciu Wiślan: „Książe pogański, silny bardzo, siedzący w Wiśle, urągał wiele chrześcijanom [...]" (Żywoty Konstantyna i Metodego. Tłum. i oprac. T. Lehr-Spławiński. Warszawa 2000, „Alfa”, s. 115). To jedyne w tej kronice wspomnienie o dawnych przodkach mieszkańców ziem polskich, których władca charakteryzuje się przede wszystkim tym, iż urąga. W swej narracji o polskich dziejach Jan Paweł II ukazuje istotną przemianę ludzkich postaw: chrześcijaństwo przezwycięża pierwotną postawę „urągania” i kształtuje postawę wdzięczności.

59 „Najpełniej znaczenie tradycji cyrylo-metodiańskiej zaprezentował [...] Jan Paweł II. Od początku pontyfikatu Papież Słowianin przypomniał, że ekumenizm jest jednym z priorytetów duszpasterskich". J. Budniak: Jednoczeni w różnorodności. Tradycja cyrylo-metodiańska jako paradygmat procesu pojednania Kościołów, kultur i narodów. Katowice 2009, UŚ, s. 11. Zob. L. Górka: Postugiwanie Jana Pawta II na rzecz pojednania chrześcijaństwa wschodniego i zachodniego. „Ethos” 2003, nr 3-4, s. 275-283. 
ływaną w papieskich przemyśleniach metaforą oddychania dwoma płucami Wschodu i Zachodu.

Jan Paweł II wypowiada się też wprost o własnym doświadczeniu, które wyniósł z czasów młodości z Wadowic jako miejscowości zróżnicowanej narodowo i religijnie, będącej jakby też obszarem kulturowego pogranicza: „Niezmiernie ważnym czynnikiem etnicznym w Polsce była także obecność Żydów. Pamiętam, że co najmniej jedna trzecia moich kolegów klasy szkoły powszechnej w Wadowicach to byli Żydzi. W gimnazjum było ich trochę mniej. Z niektórymi się przyjaźniłem. A co u niektórych z nich mnie uderzało, to był ich polski patriotyzm" ${ }^{60}$. Te słowa są świadectwem o znaczeniu obecności Żydów w wielokulturowo i wieloreligijnie pojmowanej polskości i można je też - pośrednio - odczytać jako polemikę z różnego typu antysemityzmem.

W tym miejscu papieskich wywodów w książce „Pamięć i tożsamość” pojawia się przytaczana już konkluzja: „A więc polskość to w gruncie rzeczy: wielość i pluralizm, a nie ciasnota i zamknięcie”. I dodane jest spostrzeżenie w tonie przestrogi, iż następuje jakaś niepokojąca zapaść kulturowa: „Wydaje mi się jednak, że ten jagielloński wymiar polskości, o którym wspominałem, przestał być niestety w naszych czasach czymś oczywistym" ${ }^{1}$. Przekonania o istnieniu takiej kulturowo doniosłej oczywistości nie da się woluntarystycznie skonstruować lub zadekretować (narzucić), gdyż stanowiące go treści muszą być jakby naocznie widoczne w kulturze, jakby nieodparcie przejawiać się jako cenne i niezbędne wartości w różnych sferach kultury. Aby jagielloński wymiar polskości, jako wartościowe dziedzictwo polskich dziejów, był - pozostawał - czymś oczywistym, to trzeba wciąż na nowo przezwyciężać ciasnotę i zamknięcie w ich różnorakich przejawach, a dzięki ustawicznemu kształtowaniu otwartej i spójnej tożsamości móc roztropnie kultywować wielość i pluralizm, bez rozmywania polskiej aksjosfery w niezróżnicowaną nijakość. To jest też jedno z palących zadań edukacji międzykulturowej.

\section{Inspiracje dla edukacji międzykulturowej i kształtowania tożsamości pogranicza}

Podejmując - istotną dla wychowania do kontaktów międzykulturowych kwestię jakości „polskiej prawdy” i „polskiego czynu” oraz kształtowania postaw, dzięki którym ta prawda i ten czyn uzyskają pożądaną dla nich jakość,

\footnotetext{
60 Tamże, s. 92.

61 Tamże.
} 
Jan Paweł II nawiązuje do zalecenia „Nie miłujmy słowem i językiem, ale czynem i prawdą!" $(1 \mathrm{~J} 3,18)$. Podążając tym tropem, papież kieruje wezwanie do krytycznej refleksji: „Zastanawiajmy się nad »polską prawdą«. Rozważajmy, czy jest szanowana w naszych domach, w środkach społecznego przekazu, urzędach publicznych, parafiach. Czy nie wymyka się niekiedy ukradkiem pod naporem okoliczności? Czy nie jest wykrzywiana, upraszczana? Czy zawsze jest w służbie miłości?”. W założeniu tych pytań obecna jest też przestroga, iż prawda może być poddawana destrukcyjnym dla niej zabiegom, może relatywizowana („wymykać się ukradkiem”), świadomie manipulowana i zinstrumentalizowana, traktowana jako narzędzie walki, którego ostrze kierujemy przeciwko komuś. Podobnie sformułowane jest wezwanie do krytycznej refleksji nad czynem: „Zastanawiajmy się nad »polskim czynem«. Rozważajmy, czy jest podejmowany roztropnie. Czy jest systematyczny, wytrwały? Czy jest odważny i wielkoduszny? Czy jednoczy, czy też dzieli ludzi? Czy nie uderza w kogoś nienawiścią albo pogardą" ${ }^{2}$. W założeniu tych pytań zawarte są - zespolone z sobą - wymagania etyczne i prakseologiczne wobec polskiego czynu. Są także wskazane możliwe patologie czynu, od nieroztropności i niesystematyczności, aż po podziały, które generują nienawiść i pogardę. Od tego, jaka będzie jakość „polskiej prawdy” i jak uda się przezwyciężyć patologie „polskiego czynu” będzie też zależała jakość i efektywność polskiej edukacji międzykulturowej.

Jeśli akceptuje się stanowisko Jana Pawła II, iż „pierwszym i zasadniczym zadaniem kultury w ogóle i każdej zarazem kultury jest wychowanie”, w którym przede wszystkim zmierza się do tego, aby człowiek „umiał bardziej i pełniej być człowiekiem”, a także „umiał bardziej »być« nie tylko z »drugimi«, ale także i dla »drugich «"63, to do określenia zasadniczego sensu wychowania do kontaktów międzykulturowych nie wystarcza sama opcja pragmatyczna i utylitarna, wykazująca iż takie wychowanie jest korzystne w codziennym funkcjonowaniu. Koniecznym staje się uwzględnienie wymiaru osobowego i aksjologicznego, uznanie, że edukacja międzykulturowa „wzmacnia dyspozycje, sprawności [...] niezbędne i przydatne w kontaktach międzykulturowych”, aby umożliwić spotkanie „z drugim człowiekiem przez jego kulturę, w jego kulturze” (zespolone z „dążeniem do głębszego zrozumienia go”), które jest „spotkaniem z drugim człowiekiem i jego kulturą jako

62 Jan Paweł II: Zastanawiajmy się nad »polskim czynem«. „Ethos” 2004, nr 67-68, s. 16.

63 Jan Paweł II: W imię przysztości kultury. cyt. wyd., s. 58. 
wartościami samymi w sobie” ${ }^{64}$. Takie „nastawienie wymaga przyjęcia wartości, szczególnie wyższych, uniwersalnych i ogólnoludzkich jako płaszczyzny porozumienia, wymiaru wspólnego, który łączy [...]. Bez tego etapu wszystko poza potrzebami biologicznymi wydaje się dzielić i oddalać, wzmaga poczucie obcości"65. W opartym na polskim doświadczeniu wielokulturowości i promowanym przez papieża wychowaniu do kontaktów międzykulturowych odgrywa istotną wymiar osobowy, czyli uznanie, że drugi człowiek jest tak samo osobą, jest nią pozostając zarazem „innym” i trudno zrozumiałym w wielu wymiarach swego bytowania, oraz wymiar aksjologiczny, czyli przyjęcie, iż są wspólne wartości, które mimo kulturowych różnic wyznaczają ludziom wzajemne względem siebie zobowiązania.

Jan Paweł II proponuje swój model pamięci i tożsamości człowieka pogranicza, który odwołuje się do polskiego doświadczenia wielokulturowości. Tym samym papież wpisuje się we współczesny dyskurs o funkcjach i typach pogranicza w kulturze i edukacji: „Tożsamość pogranicza, a zatem i komunikacja międzykulturowa, są dzisiaj - jak stwierdza Tadeusz Miczka - nie tylko praktyką nowego typu, ale również wyzwaniem i testem dla ludzkiej wrażliwości i twórczości, są projekcją potrzeb i postaw ludzi żyjących na pograniczu, ale także przybyszy z zewnątrz i ludzi żyjących daleko od pograniczy"66. Kształ-

64 K. Olbrycht: Rola języka wartości w wychowaniu do kontaktów międzykulturowych. W: T. Lewowicki, J. Urban, A. Szczypka-Rusz (red.): Język, komunikacja i edukacja w spotecznościach wielokulturowych. cyt. wyd., s. 189. Zob. też: M. Nowak: Komunikacyjny i interakcyjny wymiar wychowania interkulturowego. W: T. Lewowicki, J. Urban, A. Szczypka-Rusz (red): Język, komunikacja i edukacja w spotecznościach wielokulturowych. cyt. wyd., s. 41-53; P. Dancák: Komunikácia ako výchova k radikálnej otvorenosti. W: M. Pribula (red.): Orbis communicationis socialis. Prešov 2002, Gréckokatolícka teologická fakulta Prešovskej univerzity v Prešove, s. 21-29.

65 Tamże. Zob. też: K. Olbrycht: Rola ksztatcenia aksjologicznego w dziataniach pedagogicznych $w$ społecznościach wielokulturowych. W: T. Lewowicki, E. Ogrodzka-Mazur, A. Gajdzica (red.): Świat wartości i edukacja międzykulturowa. Cieszyn Warszawa 2003, UŚ - Filia w Cieszynie, Wyższa Szkoła Pedagogiczna ZNP w Warszawie, s. 212-219; taż: Pedagogiczne konsekwencje personalistycznego ujmowania kultury na progu XXI wieku. W: D. Kubinowski (red.): Kultura wspótczesna a wychowanie człowieka. Lublin 2006, UMCS, Oficyna Wydawnicza Verba, s. 79-88.

66 T. Miczka: Tożsamość na pograniczu w świetle ponowoczesności. W: I. Nowakowska-Kempna (red.): Uczeń na pograniczu językowym polsko-stowackim. Bielsko-Biała 2007, ATH, s. 16. Zob. też: M. Nowak: Wartości i kultura w kontekście pogranicza i globalizacji. W: T. Lewowicki, E. Ogrodzka-Mazur, A. Gajdzica (red.): Świat wartości i edukacja międzykulturowa. cyt. wyd., s. 22-34. 
towanie otwartej tożsamości pogranicza i ćwiczenie umiejętności (nabywanie kompetencji) komunikacji międzykulturowej, to jedne z głównych zadań edukacji międzykulturowej ${ }^{67}$, a model pamięci i tożsamości człowieka pogranicza wypracowany przez papieża może być dla tej edukacji jedną z wartych uwzględnienia propozycji. Także ze względu na wymiar religijny tego modelu. Rozpatrując rolę wychowania religijnego w wychowaniu międzykulturowym, Katarzyna Olbrycht dochodzi do konkluzji, którą odnosi się też do rozpatrywanej tu papieskiej interpretacji polskiego doświadczenia wielokulturowości jako inspiracji dla edukacji międzykulturowej: „Wychowanie do dialogu międzykulturowego nie jest łatwe. Przyznanie w nim ważnego miejsca wychowaniu religijnemu niczego nie upraszcza. Zwiększa jednak rzetelność programu wychowania międzykulturowego. Wzajemne poznanie zaczyna dotyczyć spraw wzajemnie uznanych za ważne" ${ }^{\prime 68}$. Przytoczenie i przedyskutowanie w ramach edukacji międzykulturowej papieskiej interpretacji sensu polskich dziejów i polskiego doświadczenia wielokulturowości pozwala też uwzględnić elementy wychowania religijnego $\mathrm{w}$ wychowaniu międzykulturowym, podjąć kwestie aksjologicznie doniosłe i przyczynić się do wzajemnego lepszego poznania w tym, co uważa się za egzystencjalnie ważne lub najważniejsze.

Zalecenia praktyczne oparte na analizie dążeń i dokonań Jana Pawła II w zakresie dialogu międzyreligijnego, stanowiące inspirację dla edukacji międzykulturowej, formułuje Żurek, udzielając odpowiedzi na pytanie uwzględniające kontekst współczesnej polskiej sytuacji: „Co zrobić, by nie zaprzepaścić wysiłków Papieża, co robić z papieskim przesłaniem w kraju, gdzie wyznawców innych religii jest jak na lekarstwo?”69. W zakresie edukacji kształtującej postawy i przekonania religijne „potrzebna jest katecheza wrażliwa na inne religie i dialog międzyreligijny, [...], która uczy tolerancji i umiejętności dostrzegania bogactw innych religii i tego, co nam wspólne"70.

67 „W refleksji nad kulturą wydaje się niezbędne budowanie także pewnej normatywnej wizji pogranicza, by dało się rozstrzygać, czy mamy do czynienia z blokadami czy szansami na kulturowo »życiodajny efekt pogranicza «" - L. Witkowski: Ambiwalencje tożsamości z pogranicza kulturowego. W: M. M. Urlińska (red.): Edukacja a tożsamość etniczna. Toruń 1995, UMK, s. 14.

68 K. Olbrycht: Rola wychowania religijnego w wychowaniu międzykulturowym. W: T. Lewowicki, A. Różańska, U. Klajmon (red.): Kwestie wyznaniowe w społecznościach wielokulturowych. cyt. wyd., s. 222.

69 S. J. Żurek: Potrzeba „matych Asyży”. cyt. wyd., s. 146.

70 Tamże, s. 147. „To samo, ale na głębszym poziomie, należałoby powiedzieć także w odniesieniu do edukacji seminaryjnej przyszłych księży" (tamże). Zob. też: 
W zakresie edukacji kształtującej postawy w relacjach międzyludzkich i międzykulturowych „niezbędne jest wyjście ku wyznawcom innych religii, mimo iż w naszym kraju nie ma ich wielu. Tym bardziej warto życzliwie rozglądać się wokół, by ich dostrzec i odważyć się na organizowanie naszych lokalnych czy środowiskowych małych »Asyży«. Bycie razem uczy wzajemnego zrozumienia, które najlepiej służy przezwyciężaniu stereotypów (rodem z przeszłości) w myśleniu o innych religiach. Stereotypów tych wciąż jest w Polsce wiele [...], a przeciwstawienie się im wymaga czasami nie lada odwagi, niemniej trzeba się jej uczyć”. W zakresie kształtowania postaw w życiu duchowym zaleca się zwrócenie większej uwagi na religijny i kulturotwórczy sens „uczestnictwa w spotkaniach modlitewnych, które w Polsce organizowane są już od kilku lat: Dniu Judaizmu (17 stycznia) i Dniu Islamu (25 stycznia). Dobrze by się stało, gdyby [...] wierni mogli modlić się za Żydów i muzułmanów w każdej parafii, otrzymując [...] solidną katechezę"71. Niezbędne jest też kształtowanie - ponad dzielącymi granicami wyznań i religii - wspólnej wyobraźni miłosierdzia i postawy czynnej solidarności względem osób wymagających wsparcia; jako argument przywołane są słowa papieża w meczecie Omajjadów: „Dialog międzyreligijny winien prowadzić do licznych form współpracy nade wszystko w spełnianiu obowiązku pomocy biednym i słabym"72. Dialog powinien być więc dopełniony wspólnym czynieniem miłosierdzia, a wspólne czynienie bezinteresownego dobra staje się jakby uwiarygodnieniem rzetelności dialogu.

Wskazane i rozpatrzone tu inspiracje dla edukacji międzykulturowej mogą być uznawane za „otwieranie horyzontów”, za "stawianie podstawowych pytań i przypominanie podstawowych wartości”, mogą też dawać dalsze „inspiracje dla nowego sposobu bycia człowiekiem"73. Choć wymagają one zawsze dyskusji i intelektualnie ożywczej konfrontacji z innymi punktami widzenia, aby nie stały się samowystarczalną ideologią edukacyjną i nie podzieliły losu

M. Nowak: Wychowanie interkulturowe odkrywaniem różnic. W: T. Lewowicki, A. Szczurek-Boruta, B. Grabowska (red.): Przemiany spoteczno-cywilizacyjne i edukacja szkolna - problemy rozwoju indywidualnego i kształtowanie się tożsamości. Cieszyn - Warszawa - Kraków 2005, UŚ - Filia w Cieszynie, Wyższa Szkoła Pedagogiczna ZNP w Warszawie, Oficyna Wydawnicza „Impuls”, s. 63-75.

71 Przykładem „podtrzymywania pogłębionej postawy dialogowej wśród chrześcijan są odbywające się w wielu małych miasteczkach Lubelszczyzny modlitwy mieszkańców za ich dawnych żydowskich sąsiadów" (tamże).

72 Tamże.

73 J. Tischner: Między miłosierdziem a okrucieństwem. cyt. wyd., s. 59. 
innych ideologii multikulturowości, które - konstruując nowy świat i zarazem rozmijając się z aktualną rzeczywistością społeczną - przyczyniają się do wywoływania i wzmacniania niepożądanych sytuacji.

\section{Bibliografia}

Bokszański Z.: Tożsamości zbiorowe. Warszawa 2005, PWN.

Boniecki A.: Listy przyjaciót. „Tygodnik Powszechny” 2002 (17 XI), nr 46.

Borutka T.: Wizja katolicyzmu polskiego w świetle pielgrzymek Jana Pawła II do Ojczyzny. Bielsko-Biała 1997, Instytut Teologiczny im. św. Jana Kantego.

Borutka T.: W życiu i śmierci Totus Tuus. Sylwetka duchowa, działalność pastoralna i dorobek intelektualny papieża Jana Pawła II. Kraków 2010, "Czuwajmy".

Budniak J.: Jednoczeni w różnorodności. Tradycja cyrylo-metodiańska jako paradygmat procesu pojednania Kościotów, kultur i narodów. Katowice 2009, UŚ.

Chelini J.: Powrót profetyzmu: Jan Pawet II w Polsce. „Communio”. Międzynarodowy Przegląd Teologiczny, 1998, nr 5.

Dancák P.: Otázka výchovy v náuke Jána Pavla II. Prešov 2001, Petra.

Dancák P.: Komunikácia ako výchova k radikálnej otvorenosti. W: M. Pribula (red.): Orbis communicationis socialis. Prešov 2002, Gréckokatolícka teologická fakulta Prešovskej univerzity v Prešove.

Dancák P.: Výchova k slobode ako prejav zodpovednosti za život vo filozofickej reflexii Jána Pavla II. „Theologos” 2003, nr 1.

Dancák P.: Communio personarum a európska integrácia. W: P. Dancák (red.): Sapienciálny charakter antropológie Jána Pavla II. v kontexte európskej integrácie. Zborník z vedeckého seminára s medzinárodnou účastou. Prešov 2006, Gréckokatolícka teologická fakulta Prešovskej univerzity $\mathrm{v}$ Prešove.

Dyczewski L.: Wizjoner Europy. „Ethos” 2003, nr 3-4.

Dyczewski L.: Od tożsamości zamkniętej do otwartej w społeczeństwie wielokulturowym i globalnym. W: T. Lewowicki, J. Urban, A. Szczypka-Rusz (red.): Język, komunikacja i edukacja w społecznościach wielokulturowych. Cieszyn - Warszawa 2004, UŚ - Filia w Cieszynie, Wyższa Szkoła Pedagogiczna ZNP w Warszawie. 
Dzwonkowski R.: Papież Jan Pawet II a Polonia i Polacy za granica. „Ethos” 2003, nr 3-4.

Federowicz A., Federowicz T., Swieżawski S., Wojtyła K: Petny wymiar. Listy przyjaciót. Opracował A. Dobrowolski. Tarnów 2002, Biblos.

Górka L.: Postugiwanie Jana Pawła II na rzecz pojednania chrześcijaństwa wschodniego i zachodniego, „Ethos” 2003, nr 3-4.

Jan Paweł II: Wimię przyszłości kultury. Przemówienie w siedzibie UNESCO, Paryż, 2 VI 1980. W: tenże: Wiara i kultura. Dokumenty, przemówienia, homilie. Wybór i oprac. M. Radwan, S. Wylężek, T. Gorzkula. Rzym Lublin 1988, KUL.

Jan Paweł II: Niech się zjednoczq w naszej świadomości dwie kobiece postaci: królowa i służaca. Homilia wygłoszona na Rynku Krakowskim podczas Mszy św. beatyfikacyjnej Sługi Bożej Anieli Salawy, 13 sierpnia 1991. W: Jan Paweł II: Otrzymaliście ducha przybrania za synów. Drugi etap czwartej wizyty duszpasterskiej w Polsce 13-16 sierpnia 1991 roku. Watykan 1992, Libreria Editrice Vaticana.

Jan Paweł II: Przekroczyć próg nadziei. Jan Pawet II odpowiada na pytania Vittoria Messoriego. Lublin 1994, KUL.

Jan Paweł II: Chrystus - źródto nowej kultury dla Europy. Do uczestników przedsynodalnego sympozjum poświęconego Europie (14 I 1999). "L'Osservatore Romano" wyd. polskie 1999, nr 3.

Jan Paweł II: List do kard. Miloslava Vlka, przewodniczacego Rady Konferencji Episkopatów Europy (16 października 2000 r.). „L'Osservatore Romano” wyd. polskie 2001, nr 1.

Jan Paweł II: Przemówienie do grupy chrześcijańskich deputowanych do Parlamentu Europejskiego, Rzym, 6 marca 1997. W: S. Sowiński, R. Zenderowski: Europa droga Kościoła. Jan Pawet II o Europie i europejskości. Wrocław 2003, Zakład Narodowy im. Ossolińskich.

Jan Paweł II: Autobiografia. Wybrała i ułożyła J. Kiljańczyk-Zięba. Kraków 2003, WL.

Jan Paweł II: Zastanawiajmy się nad »polskim czynem «. „Ethos” 2004, nr 67-68 .

Jan Pawet II o dziejach Polski. Wybór i oprac. A. Zwoliński. Radom 2004, POLWEN.

Jan Paweł II: Być człowiekiem sumienia. Bielsko-Biała 2005, Kuria Diecezji Bielsko-Żywieckiej. 
Jan Paweł II: Pamięć i tożsamość. Rozmowy na przetomie tysiącleci. Kraków 2005, „Znak”.

Jan Paweł II: Ojczyzna. Warszawa 2008, New Media Concept.

Jędraszewski M.: Wybrać większq wolność. Karol Wojtyła o człowieku. Poznań 2004, Księgarnia św. Wojciecha.

Juros H.: Piotr naszych czasów. „Więź” 1983, nr 8-10.

Juros H.: Nowe zadania Kościoła w Polsce. „Przegląd Powszechny” 1993, nr 1 (857).

Juros H.: Nauka, polityka naukowa i ludzie nauki w życiu Karola Wojtyty. Przyczynek do biografii naukowej Profesora i Papieża. „Nauka” 2005, nr 3.

Kalinowski G.: Nauka i kultura w stużbie człowieka: Jan Pawet II. „Communio". Międzynarodowy Przegląd Teologiczny 1998, nr 5.

Lewowicki T.: W poszukiwaniu modelu edukacji międzykulturowej. W: T. Lewowicki, E. Ogrodzka-Mazur, A. Szczurek-Boruta (red.): Edukacja międzykulturowa $w$ Polsce i na świecie. Katowice 2000, UŚ.

Lewowicki T.: Edukacja międzykulturowa - bilans otwarcia 2012. „Edukacja Międzykulturowa" 2012, nr 1.

Miczka T.: Tożsamość na pograniczu w świetle ponowoczesności. W: I. Nowakowska-Kempna (red.): Uczeń na pograniczu językowym polsko-stowackim. Bielsko-Biała 2007, ATH.

Nikitorowicz J.: Pogranicze - Tożsamość - Edukacja międzykulturowa. Białystok 2001, „Trans Humana”.

Nikitorowicz J.: Edukacja międzykulturowa. W: T. Pilch (red.): Encyklopedia pedagogiczna XXI wieku. T. 1. Warszawa 2003, „Żak”.

Nikitorowicz J.: Edukacja regionalna i międzykulturowa. Warszawa 2009, WAiP.

Nikitorowicz J.: Fenomen wielokulturowości i prognozy rozwoju ku międzykulturowości. „Edukacja Międzykulturowa” 2012, nr 1.

Nowak M.: Wartości i kultura w kontekście pogranicza i globalizacji. W: T. Lewowicki, E. Ogrodzka-Mazur, A. Gajdzica (red.): Świat wartości i edukacja międzykulturowa. Cieszyn - Warszawa 2003, UŚ - Filia w Cieszynie, Wyższa Szkoła Pedagogiczna ZNP w Warszawie.

Nowak M.: Komunikacyjny i interakcyjny wymiar wychowania interkulturowego. W: T. Lewowicki, J. Urban, A. Szczypka-Rusz (red.): Język, komunikacja $i$ edukacja w społecznościach wielokulturowych. Cieszyn - Warszawa 2004, UŚ - Filia w Cieszynie, Wyższa Szkoła Pedagogiczna ZNP w Warszawie. 
Nowak M.: Wychowanie interkulturowe odkrywaniem różnic. W: T. Lewowicki, A. Szczurek-Boruta, B. Grabowska (red.): Przemiany społeczno-cywilizacyjne i edukacja szkolna - problemy rozwoju indywidualnego $i$ ksztattowanie się tożsamości. Cieszyn - Warszawa - Kraków 2005, UŚ - Filia w Cieszynie, Wyższa Szkoła Pedagogiczna ZNP w Warszawie, Oficyna Wydawnicza „Impuls”.

Ogrodzka-Mazur E.: Kategoria tożsamości w analizach zmiany społecznej. Implikacje pedagogiczne do badań edukacji międzykulturowej. W: T. Lewowicki, E. Ogrodzka-Mazur (red.): W poszukiwaniu teorii przydatnych w badaniach międzykulturowych. Cieszyn 2001, UŚ - Filia w Cieszynie.

Ogrodzka-Mazur E.: Społeczne nauczanie Jana Pawła II a miłość, prawda i tolerancja $w$ wychowaniu mtodzieży z pogranicza. W: T. Lewowicki, A. Różańska, U. Klajmon (red.): Kwestie wyznaniowe w społecznościach wielokulturowych. Cieszyn 2002, UŚ - Filia w Cieszynie.

Ogrodzka-Mazur E.: „Nowy nieporzadek świata” a kształtowanie (się) tożsamości globalnej. Ku pedagogice odpowiedzialności w XXI wieku. W: T. Lewowicki, E. Ogrodzka-Mazur, J. Urban (red.): Społeczne uwarunkowania edukacji międzykulturowej. Konteksty teoretyczne. T. 1. Cieszyn - Warszawa - Toruń 2009, Wydział Etnologii i Nauk o Edukacji Uniwersytetu Śląskiego, Wyższa Szkoła Pedagogiczna ZNP w Warszawie.

Olbrycht K.: Prawda, dobro i piękno w wychowaniu człowieka jako osoby. Katowice 2002, UŚ.

Olbrycht K.: Rola wychowania religijnego w wychowaniu międzykulturowym. W: T. Lewowicki, A. Różańska, U. Klajmon (red.): Kwestie wyznaniowe w społecznościach wielokulturowych. Cieszyn 2002, UŚ - Filia w Cieszynie. Olbrycht K.: Rola kształcenia aksjologicznego w działaniach pedagogicznych w społecznościach wielokulturowych. W: T. Lewowicki, E. Ogrodzka-Mazur, A. Gajdzica (red.): Świat wartości i edukacja międzykulturowa. Cieszyn - Warszawa 2003, UŚ - Filia w Cieszynie, Wyższa Szkoła Pedagogiczna ZNP w Warszawie.

Olbrycht K.: Rola języka wartości w wychowaniu do kontaktów międzykulturowych. W: T. Lewowicki, J. Urban, A. Szczypka-Rusz (red.): Jezzyk, komunikacja i edukacja w społecznościach wielokulturowych. Cieszyn - Warszawa 2004, UŚ - Filia w Cieszynie, Wyższa Szkoła Pedagogiczna ZNP w Warszawie.

Olbrycht K.: Pedagogiczne konsekwencje personalistycznego ujmowania kultury na progu XXI wieku. W: D. Kubinowski (red.): Kultura wspótczesna 
a wychowanie człowieka. Lublin 2006, UMCS, Oficyna Wydawnicza Verba.

Poupard P. Kard.: Ten papież jest darem od Boga. Rozmowa z Marie-Joelle Guillaume. Wstęp abp J. Życiński. Katowice 2002, Księgarnia św. Jacka. Salij J.: Patriotyzm dzisiaj. Poznań 2005, W drodze.

Sowiński S., Zenderowski R.: Europa droga Kościoła. Jan Pawet II o Europie i europejskości. Wrocław 2003, Zakład Narodowy im. Ossolińskich.

Styczeń T., SDS: Doświadczenie człowieka i świadczenie człowiekowi. „Znak” 1980, nr 3.

Szczurek-Boruta A.: Edukacja i odkrywanie tożsamości w warunkach wielokulturowości. Szkice pedagogiczne. Katowice - Cieszyn - Kraków 2007, UŚ, Oficyna Wydawnicza „Impuls”.

Szostek A., MIC: Doświadczenie człowieka i moralności w ujęciu kardynała Karola Wojtyty. „Znak” 1980, nr 3.

Szostek A. MIC: Człowiek droga Kościoła. Główne linie pontyfikatu Jana Pawta II. „Ethos”, numer specjalny 2005.

Szostek A.: Od samostanowienia do daru z siebie i uczestnictwa. O Karola Wojtyty/Jana Pawła II koncepcji wolności. „Nauka” 2005, nr 3.

Tischner J.: Między miłosierdziem a okrucieństwem. W: J. Tischner: Idac przez puste Błonia. Wybór i oprac. W. Bonowicz. Kraków 2005, „Znak”.

Wierzbicki A. M.: Stawialiśmy się społeczeństwem teologicznym. Wstęp. W: A. M. Wierzbicki: Polska Jana Pawła II. Lublin 2011, KUL.

Witkowski L.: Ambiwalencje tożsamości z pogranicza kulturowego. W: M. M. Urlińska (red.): Edukacja a tożsamość etniczna. Toruń 1995, UMK.

Wojtyła K.: Problem doświadczenia w etyce. „Roczniki Filozoficzne” 1969, z. 2.

Wolsza K.: Aksjologiczna struktura człowieka a problem ontycznych podstaw moralności. W: P. Morciniec (red.): Ocalić obraz człowieka. Antropologiczne podstawy moralności. Opole 2003, UO.

Wolsza K.: Prawa człowieka - lista życzeń czy wyraz afirmacji osoby? W: K. Wolsza (red.): Współczesne dylematy etyczne. Opole 2005, UO.

Zenderowski R.: Religia a tożsamość narodowa i nacjonalizm w Europie Środkowo-Wschodniej. Między etnicyzacja religii a sakralizacja etnosu (narodu). Wrocław 2011, UWr.

Żurek S. J.: Potrzeba „matych Asyży”. „Więź” 2005, nr 5-6.

Żywoty Konstantyna i Metodego. Tłum. i oprac. T. Lehr-Spławiński. Warszawa 2000, „Alfa”. 


\section{Polish experience of multiculturalism in the interpretation of John Paul II as an inspiration for intercultural education}

\section{Summary}

The inquiry aims at indicating that the interpretation of Polish experience of multiculturalism performed by John Paul II may become an inspiration for intercultural education and comparative pedagogy of religion. This can occur mainly because the issue of particularity and universality, which is considered significant for research into intercultural education, is present in the interpretation of Polish experience of multiculturalism carried out by John Paul II. He combined Polish experience of multiculturalism with his own personal experience which shaped his identity as well as with moral experience and experiencing the Christian faith. For those who share axiological convictions promoted by John Paul II, his interpretation of Polish experience of multiculturalism has become crucial. They can see significant merits of the papal interpretation of the Polish ethos. If this interpretation is granted rightness, it acquires the qualities of an intellectually and morally important point of reference for the axiological and educational sense of Polish experience of multiculturalism. The issues of intercultural education and comparative pedagogy of religion were frequently undertaken by John Paul II. In his book Pamięć $i$ tożsamość. Rozmowy na przełomie tysiacleci /Memory and Identity: Conversations at the Dawn of a Millennium/, in which John Paul II recapitulates his philosophical and theological considerations on culture, his convictions concerning Polish experience of multiculturalisms are also expressed: 'Polishness is in fact multitude and pluralism, not narrowness and confinement. It seems, however, that this »Jagiellonian « dimension of Polishness [...] ceased to be, unfortunately, something obvious in our times ${ }^{774}$. What is essential for intercultural education is the recognition that Polishness is marked by 'multitude and pluralism, not narrowness and confinement', because in this way axiological principles of shaping beliefs and attitudes in interpersonal relations are created in the complex situation of multiculturalism.

74 Jan Paweł II: Pamięć i tożsamość. Rozmowy na przełomie tysiącleci. cyt. wyd., s. 92. 
Key words: education, intercultural education, comparative pedagogy of religion, John Paul II, Polish experience of multiculturalism, educational sense of Polish experience of multiculturalism, pluralism

Translated by Agata Cienciała 